\title{
Taxonomy and palaeoecology of brachiopods from the South-Helvetic zone of the Fäneren region (Lutetian, Eocene, NE Switzerland)
}

\author{
Heinz Sulser • Diego García-Ramos • \\ Peter Kürsteiner • Ursula Menkveld-Gfeller
}

Received: 18 May 2009/Accepted: 5 July 2010/Published online: 12 August 2010

(C) Swiss Geological Society 2010

\begin{abstract}
Terebratuloid and cancellothyridoid brachiopods from the South-Helvetic Lutetian (Eocene) of the Fäneren region (NE Switzerland) are described: Carneithyris subregularis (QUENSTEDT) and two forms of Terebratulina s.l. under open nomenclature. Several species of Alpine and non-Alpine origin, related to Carneithyris subregularis, like Terebratula kickxi GALEOTTI, Terebratula aequivalvis SCHAFHÄUTL and Terebratula hilarionis DAVIDSON show characters, which compare well with Carneithyris subregularis. Two of them, T. aequivalvis and T. hilarionis, are assigned to the genus Carneithyris. The stratigraphy and lithology of the sediments in the study area are reassessed. Life habits and palaeoecology of the brachiopods are discussed. C. subregularis apparently was a free living brachiopod without attachment to the substrate, as indicated by massive accumulations of
\end{abstract}

Editorial handling: David A. T. Harper \& Daniel Marty.

H. Sulser $(\bowtie)$

Paläontologisches Institut und Museum der Universität Zürich,

Karl Schmid-Strasse 4, 8006 Zürich, Switzerland

e-mail: heinz.sulser@sunrise.ch

D. García-Ramos

Asociación Cultural Paleontológica Murciana, Instituto Severo

Ochoa, Camino Tiñosa 50, 30158 Los Garres, Murcia, Spain

P. Kürsteiner

Alpsteinstrasse 28, 9240 Uzwil, Switzerland

U. Menkveld-Gfeller

Naturhistorisches Museum der Burgergemeinde Bern,

Bernastrasse 15, 3005 Bern, Switzerland callosities in the posterior parts of the shell. The variability of the cardinal process, as seen in the studied Carneithyris group can be interpreted as a morphological element to enlarge the surface of attachment of strong diductor muscles in relation to the internal thickening of the individual.

Keywords Brachiopoda - Carneithyris - Eocene · South-Helvetic · Palaeoecology

Zusammenfassung Terebratuloide und Cancellothyridoide Brachiopoden aus dem Südhelvetischen Lutetian (Eozän) des Fänerengebietes in der Nordost-Schweiz werden beschrieben: Carneithyris subregularis (QUENSTEDT) sowie zwei Formen von Terebratulina s.l. von noch undefinierter Art. Verschiedene alpine und nicht-alpine, mit Carneithyris subregularis verwandte Spezies, wie Terebratula kickxi GALEOTTI, Terebratula aequivalvis SCHAFHÄUTL und Terebratula hilarionis DAVIDSON zeigen Merkmale, die sich gut mit Carneithyris subregularis vergleichen lassen. Zwei von ihnen, T. aequivalvis und T. hilarionis können Carneithyris zugewiesen werden. Die Stratigraphie und Lithologie der Sedimente im Arbeitsgebiet werden neu untersucht. Lebensweise und Palökologie der Brachiopoden werden diskutiert. C. subregularis scheint freilebend ohne Anheftung auf dem Substrat gelebt zu haben, worauf massive Callusbildung im Schlossbereich hinweist. Die Variabilität des Cardinalfortsatzes in der untersuchten Carneithyris-Gruppe kann als ein morphologisches Element gedeutet werden, das, in Relation zur internen Verdickung der Schale, durch Vergrösserung der Oberfläche eine Verstärkung der Diduktormuskeln erlaubt. 


\section{Introduction}

Despite the marked worldwide decline in biodiversity at the beginning of the Cenozoic Era, the brachiopods remain relatively common today, even though they have lost their dominance as a significant faunal element amongst the epibenthos. In the Tertiary Period brachiopods in Switzerland are rare with only a few published reports. For example, from the marine Miocene "Obere Meeresmolasse", the inarticulate genus Lingula is described (Bachmann 1867; Rutsch 1928; Büchi 1955). It sporadically occurs together with a rich fauna of bivalves and gastropods. In the Subalpine Oligocene "Untere Meeresmolasse", brachiopods seem to be completely absent, whereas in sediments of the same stage in the Jura Mountains of NW Switzerland, some poorly known species occur (Mayer 1864; Greppin 1870; Kissling 1896).

The sparse presence of brachiopods in the Paleogene of the Alpine Helvetic zones had been noted by a number of authors (Mayer 1877, 1879; Mayer-Eymar 1890). Later, during the early 1900s, the area of the Fäneren region in NE Switzerland was the subject of detailed geological investigations by Heim (1923a, b). He supported the thesis that these sediments, in spite of their content of nummulitids, were of Cretaceous and not of Paleogene age. He based his arguments on the identification of Cretaceous ammonites (later shown to be reworked) and the misinterpretation of the tectonically complicated, scattered distribution of these strata. Rollier (1923) supported Heim's position, mainly on the grounds of the available palaeontological data, and consequently assigned the relevant fossils to Cretaceous taxa. This stratigraphical problem has since been clarified (Richter 1925; Eugster 1931), and the nummulitic beds are now properly recognized as Paleogene sediments (Herb 1988; Decrouez and Menkveld-Gfeller 2003).

Interest in the brachiopods of the Fäneren region was again revived, when new samples yielded material that has permitted a revision of the current unsatisfactory taxonomic position of these brachiopods. This is the main purpose of the present paper. Related brachiopods of the European Paleogene are included in the discussion where relevant.

\section{Geographical and geological setting}

The pyramide-like Fäneren Mountain with its peak at 1,505.8 $\mathrm{m}$ height is located between the Rhine valley and the village of Appenzell in NE Switzerland (Fig. 1). Towards the north, the landscape is characterized by several hills and then generally flattens. In the south and southwest of the Fäneren lie the chains of Alpstein with the highest elevation at Säntis $(2,503.1 \mathrm{~m})$.

The brachiopods described in this study originate from the so-called "Schuppenzone of Brülisau" and the
Fig. 1 a Geographic map of the study area (black rectangle) in Canton Appenzell I.R., NE Switzerland. b Enlarged area with Swiss cartesian coordinates, labelled in $\mathrm{km}$. Sketch with the localities of Eocene outcrops which yielded a fauna containing brachiopods. 1 Obere Leugangen north, 2 Gfell, Brülisau, small stream, 3 Schluecht-Töbeli north, 4 Southwest of Blosers, 5 Aulenbachtobel southeast, 6 Aulenbachbrücke, left pier, 7 Chlus-Höllflätschen, south side, 8 Chlus-Höllflätschen, north side, 9 Aebiskraut, quarry, 10 Langwald east, Eggerstanden, 11 Schörgischnorren,

Kobelwies. The outcrops 1-6 and $9-11$ are situated in the tectonic zone of the "Schuppenzone of Brülisau", 7 and 8 in the zone of the "Flammenegg-Zug"

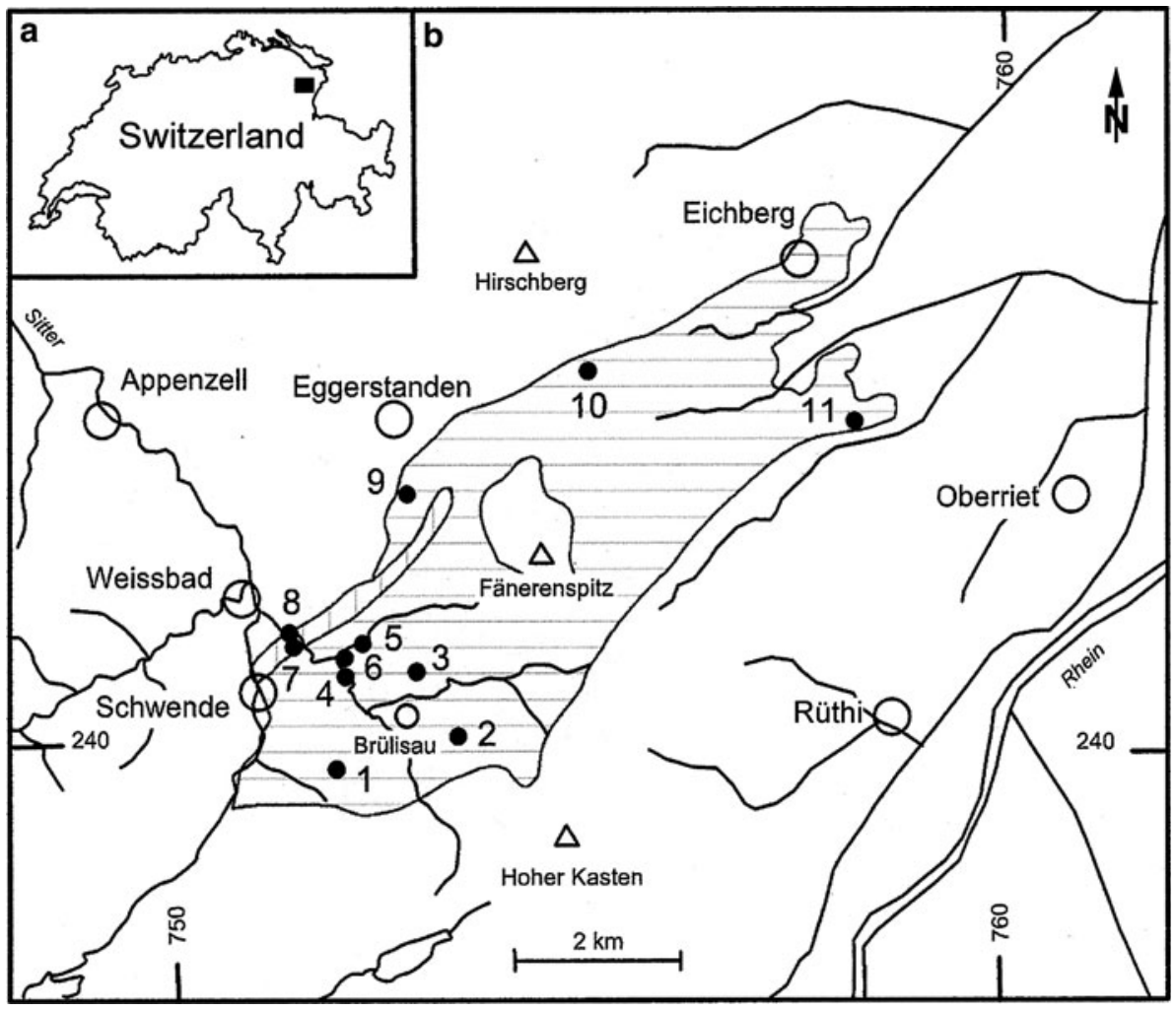


Fig. 2 Geological and tectonical setting of the Fäneren region (modified after Kürsteiner and Soom 2007 and Eugster et al. 1982)
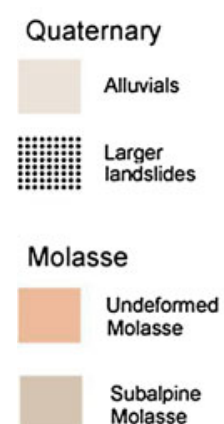

Helvetic

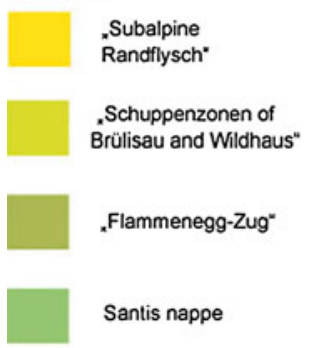

Penninic

Northpenninic flysch

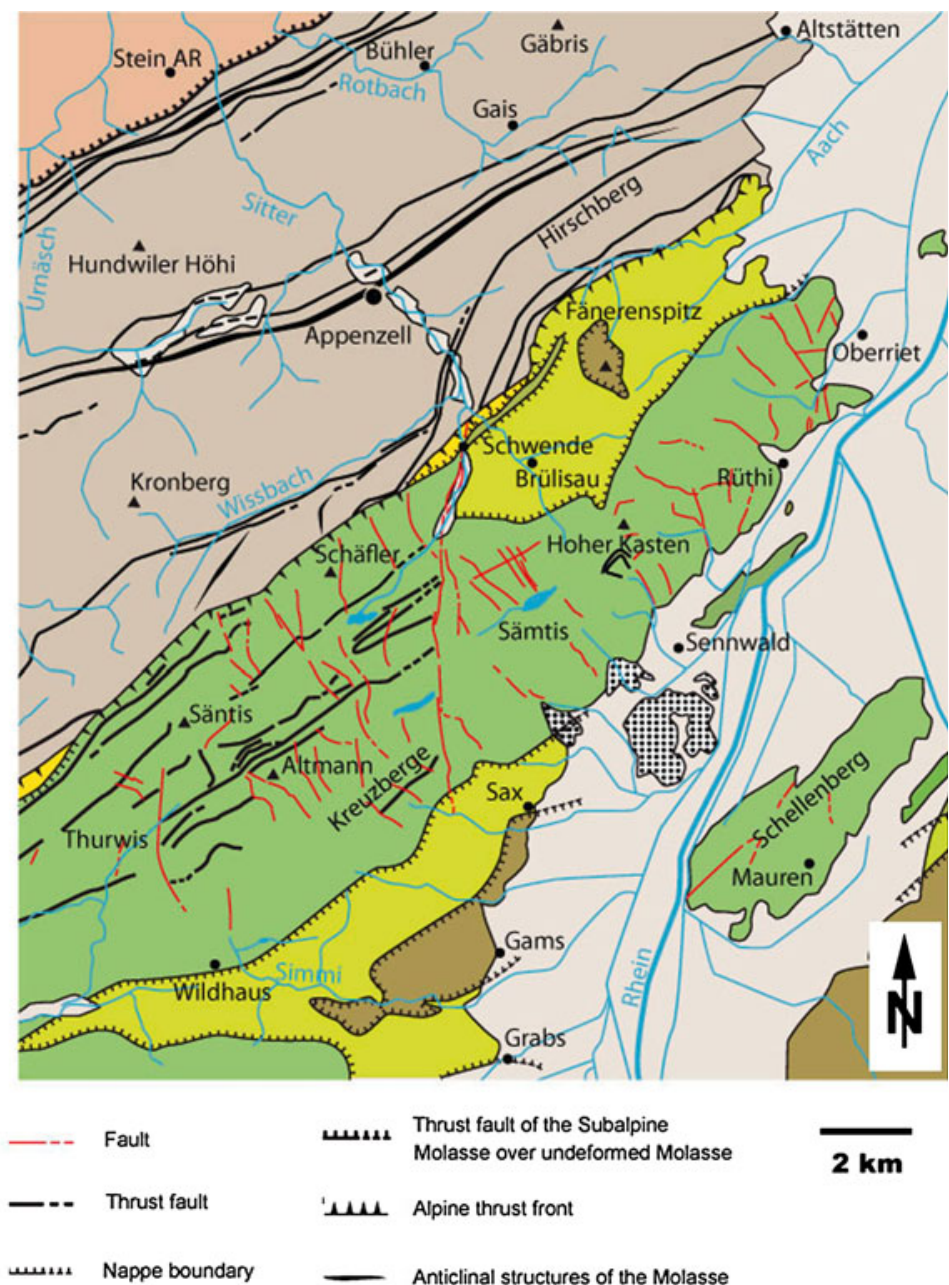

"Flammenegg-Zug" (Figs. 1, 2). During the Alpine Orogeny, the sediments of the Alpstein massif were detached, along the basal Cretaceous, from the original Jurassic substratum that remained in the south (Heim 1905; Pfiffner 2000). This Helvetic Säntis nappe was thrust over the Tertiary sediments of the Subalpine Molasse and a narrow tectonised zone, the subalpine "Randflysch-Zone". South-Helvetic sediments, originally deposited south of the Säntis nappe, were in turn thrust over that nappe. Today they are situated in numerous spot-like outcrops on the slopes of the Fäneren Mountain. Two tectonic units can be distinguished. The "Flammenegg-Zug" contains Eocene sediments of the Bürgen Formation overlying the Seewen Formation deposits of Late Cretaceous age, and the "Schuppenzone of Brülisau" contains the Amden or Wang Formation covered by Eocene sediments comprising neritic "Gallensis-Schichten", followed by the Stad Formation (formerly called the "Globigerinen-Schiefer") and "Wildflysch". The peak of the Fäneren Mountain forms a "Klippe" of North-Penninic origin, containing Cretaceous sandstones and limestones with fucoid trace fossils (Egger and Oberhauser 2007). The "Schuppenzone of Wildhaus", situated south-east of the Alpstein massif, is a lateral equivalent of the unit at Brülisau and was not included in this study.

Herb (1988) analysed the palaeogeographic distribution of the Eocene sediments and assigned these limestones (partly glauconitic sands) to the informal lithostratigraphical unit called "Gallensis-Schichten", a transitional facies between the Einsiedeln Formation in the south-east and the Bürgen Formation in the north-west of the Helvetic zone. The limestones (Upper Ypresian-basal Lutetian) were ascribed to the Einsiedeln Formation, and the glauconitic sandstone ("Greensand" of Early Lutetian age) to the Bürgen Formation (Menkveld-Gfeller 1997). The southern outcrops of the "Schuppenzone of Brülisau" expose the "Gallensis Limestone", whereas in the north, the "Gallensis Greensand" dominates. All the brachiopods recovered from the "Schuppenzone" originate from sediments with Nummulites and Assilina indicating an Early Lutetian age. In the "Flammenegg-Zug", Lutetian Greensand of the Bürgen Formation, rich in Assilina, has also been sampled. 
Table 1 Localities indicated on Fig. 1, related to tectonic units, and the occurrence of brachiopods

+ presence confirmed, ++ well preserved, - not found

\begin{tabular}{lllll}
\hline Locality & Tectonic unit & $\begin{array}{l}\text { Carneithyris } \\
\text { subregularis }\end{array}$ & $\begin{array}{l}\text { Terebratulina } \\
\text { sensu lato }\end{array}$ & $\begin{array}{l}\text { Carneithyris } \\
\text { aequivalvis }\end{array}$ \\
\hline Obere Leugangen & Schuppenzone & ++ & - & - \\
Gfell & Schuppenzone & + & - & - \\
Schluecht-Töbeli & Schuppenzone & ++ & - & + \\
Brülisaubach & Schuppenzone & + & - & - \\
Aulenbachtobel & Schuppenzone & + & - & - \\
Aulenbachbrücke & Schuppenzone & + & - & - \\
Chlus-Höllflätschen south & Flammenegg-Zug & + & + & - \\
Chlus-Höllflätschen north & Flammenegg-Zug & + & - & + \\
Aebiskraut & Schuppenzone & + & - & - \\
Langwald & Schuppenzone & + & + & - \\
Schörgischnorren & Schuppenzone & + & - & - \\
\hline
\end{tabular}

\section{Studied localities}

In both, the "Schuppenzone of Brülisau" and the "Flammenegg-Zug", the conditions for sampling are not ideal. There are over 40 isolated, small exposures of "Gallensis Greensand", mostly in loose blocks, and separated from their solid outcrop. Similarly, the "Gallensis Limestone" crops out in small areas with a wide distribution. Lenses with masses of tightly packed red algal limestone ("Lithothamnien-Riffe") are inserted in the limestone. The most spectacular of these peculiar facies is situated at the north-western slope (Aebiskraut) of the Fäneren peak.

Some 30 localities in both tectonic units were investigated by one of us (P.K.) with regard to their fossil assemblages (Fig. 1; Table 1). In one-third of them the presence of the main representative of the brachiopod fauna, Carneithyris subregularis, was present, but only at Obere Leugangen and Schluecht-Töbeli, the weathered sediment enabled the extraction of well preserved conjoined shells. The sediments from these localities were correlated with the basal Lutetian by the presence of Nummulites gallensis, $N$. cf. uronienesis and Assilina of the group Assilina exponens. Specimens of Terebratulina s.l. were recovered from the localities at Langwald and ChlusHöllflätschen (Table 1). Despite several intense searches in the red algal limestone at Aebiskraut only a single specimen, assigned to Carneithyris aff. aequivalvis, was found. Characteristic Nummulites or Assilina species for age determination were absent in these recently collected samples, but Heim (1923a, p. 25; 1923b) described Nummulites gallensis and other Nummulitids indicating a basal Lutetian age from this site. The facies of this limestone strongly resembles the Einsiedeln Limestone of Late Ypresian to Early Lutetian age.

\section{Materials and methods}

Most brachiopods that could be collected were either damaged or their extraction from the rock matrix was not possible. The mantle cavity was usually filled with coarse particles of detritus and fragments of nummulitids, and thus the delicate parts of the internal structures were frequently destroyed. Specimens in a perfect state, suitable for detailed studies, were comparatively rare. Most brachiopods were recovered as internal moulds, in some cases with remnants of abraded calcitic shell. Figured in anterior view, the shell is orientated with dorsal valve up.

Transverse serial sections were made with cellulose acetate peels. Numbers indicate the distance from the posterior end to the plane of section in mm. Longitudinal sections, parallel to the commissural plane were obtained in the same way. Selected sections showing characteristic features were illustrated by photomicrographs.

In addition to the newly collected specimens, collections with fossils from the Fäneren region were consulted in the following museums and institutions: Natural Museum of St. Gallen (NMSG); Natural Museum of Bern (NMBE); Palaeontological Institute and Museum of the University of Zurich (PIMUZ); Inatura Dornbirn Austria (Inatura); Museo di Geologia e Paleontologia, Università degli Studi, Padova Italia (MGPD).

\section{Systematic palaeontology}

Phylum Brachiopoda DuMÉRIL 1806

Subphylum Rhynchonelliformea WiLLIAMS ET AL. 1996

Class Rhynchonellata WILLIAMS ET AL. 1996

Order Terebratulida WAAGEN 1883

Suborder Terebratulidina WAAGEN 1883 
Fig. 3 Carneithyris

subregularis (Quenstedt 1871).

a Lectotype, figured in

Quenstedt (1871), pl. 48,

fig. 29, in dorsal, ventral, lateral and anterior view, "Flysch" of Schwendi, Fäneren region, Canton Appenzell I.R., NE Switzerland. b Specimen, figured in Ooster (1863), pl. 9, fig. 1, Eocene (Lutetian) of "Schöneck" (the obsolete site name may in fact be Schienegg, now spelled Schaienegg), in dorsal, ventral, lateral and anterior view (NMBE 5015781). c Specimen in dorsal, lateral and anterior view, Eocene (Lutetian), SchluechtTöbeli, Fäneren area (collection P. Kürsteiner). d Three specimens, Eocene (Lutetian), Fäneren area, illustrating the variability of outline in dorsal views (NMSG P. 1001- P. 1003). e Specimen in dorsal, ventral, lateral and anterior view, Eocene (Lutetian), Surbrunnen/Gschwänd near Oberiberg, Canton Schwyz, Switzerland (PIMUZ 27582). All scale bars: $1 \mathrm{~cm}$
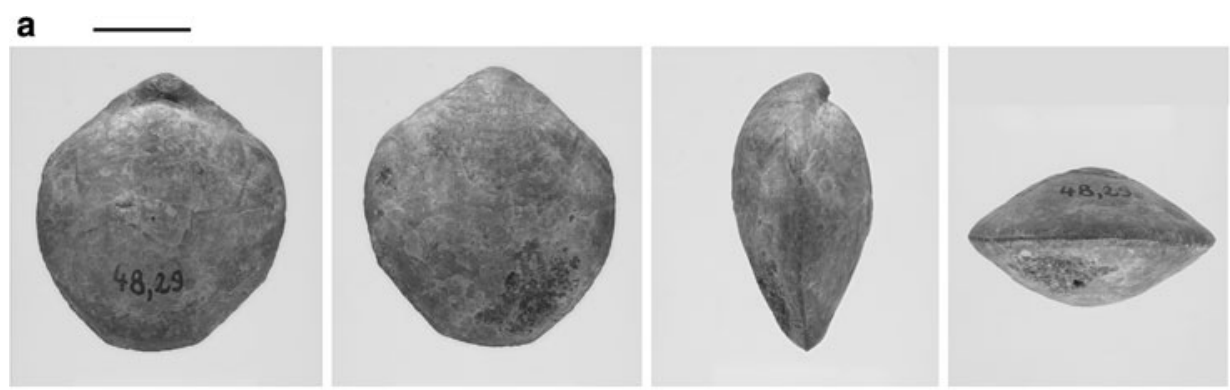

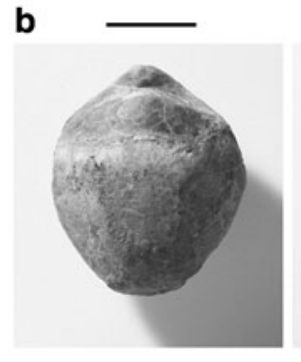

C
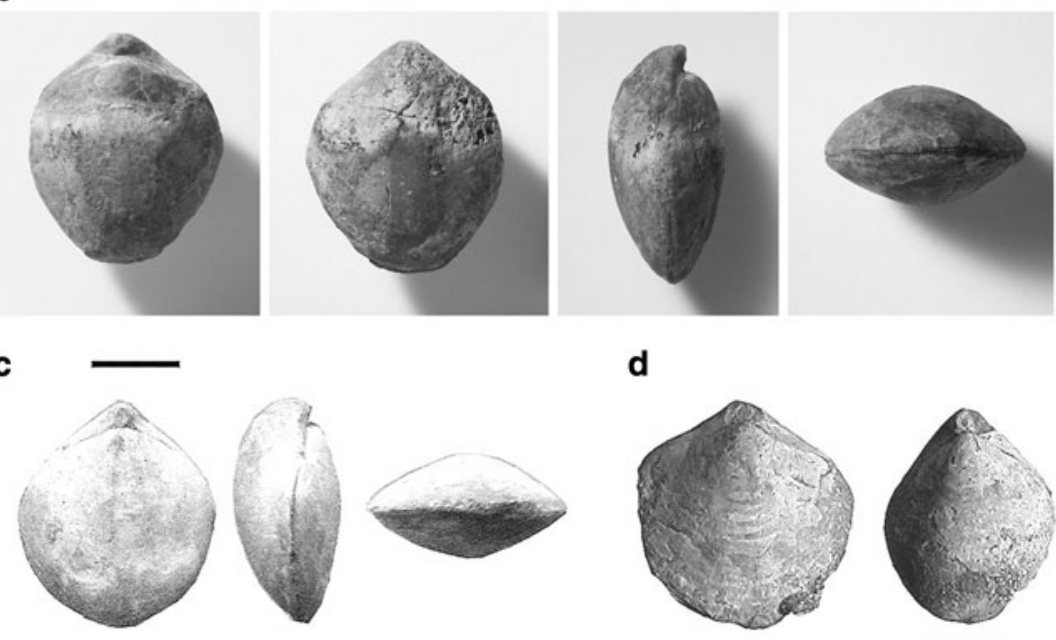

d
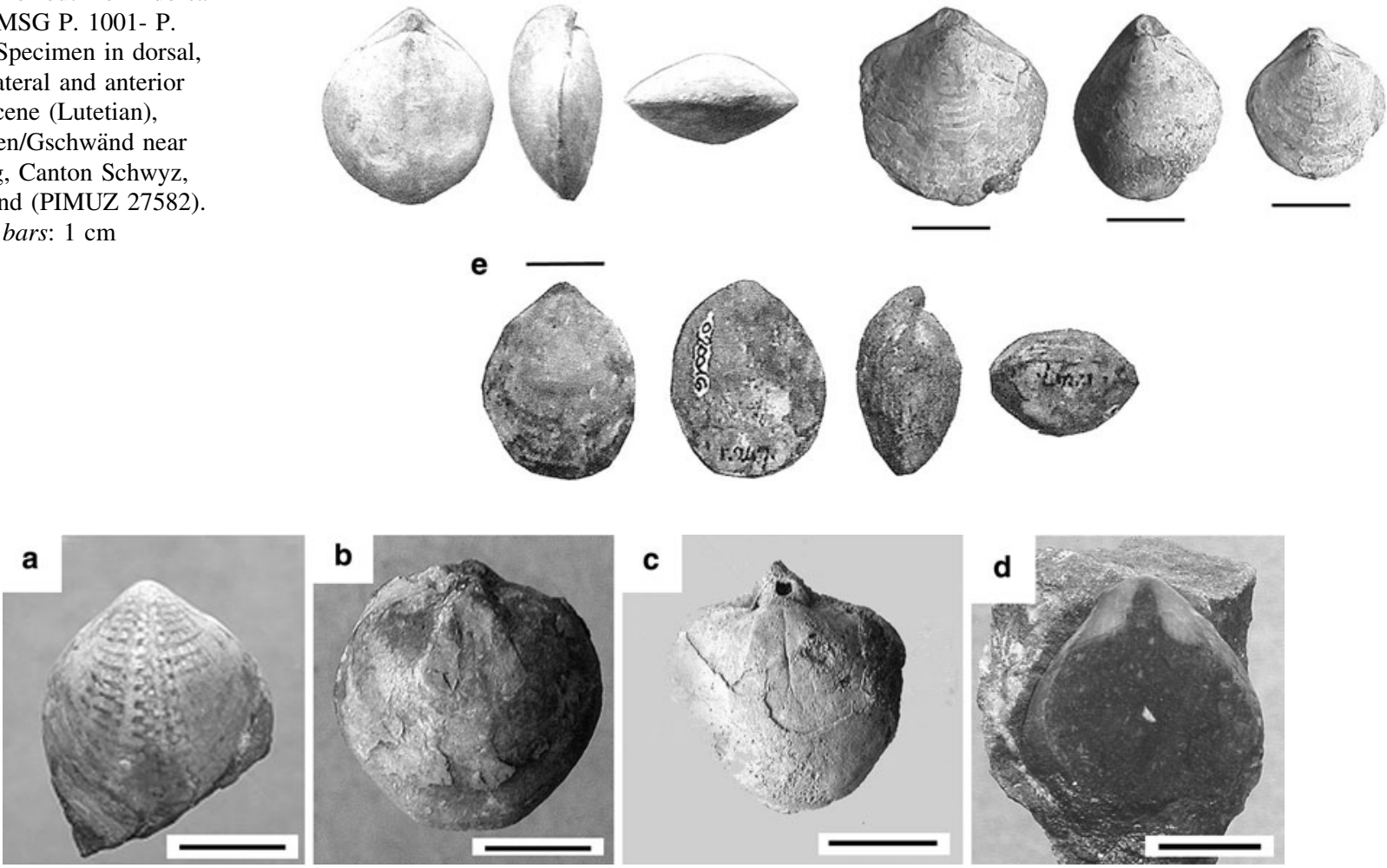

Fig. 4 Carneithyris subregularis (Quenstedt 1871). Different specimens, Fäneren area. a Shell ornament (NMSG P. 1004). b Internal mould with spatula-like adductor muscle scars on dorsal valve (NMSG P. 1005). c Internal mould of an odd-shaped beak area,

Carneithyris subregularis (QuenstedT 1871) (Figs. 3, 4, 5)

Superfamily Terebratuloidea GRAY 1840

Family

Gibbithyrididae MuIR-Wood 1965

Subfamily

Carneithyridinae MuIR-WoOd 1965

Genus
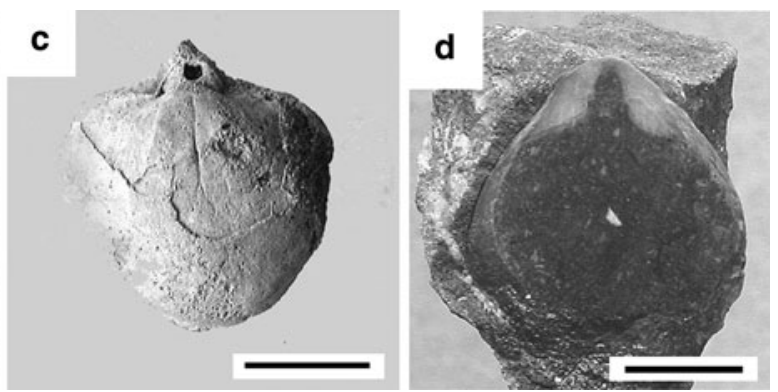

sculptured by callosities in posterior part of the shell (NMSG P. 1006). d Longitudinal shell cut, showing white infillings of calcite accumulation in the beak area (NMSG P. 1007). All scale bars: $1 \mathrm{~cm}$

Type species C. subpentagonalis (original designation)

1828 Terebratula subregularis MÜNSTER: 99

1861 Terebratula subregularis MÜNSTER; GÜMBEL: 597

1863 Terebratula Kickxii GaleotTi; Ooster: 24-25; pl. 9 , fig. 1 
a
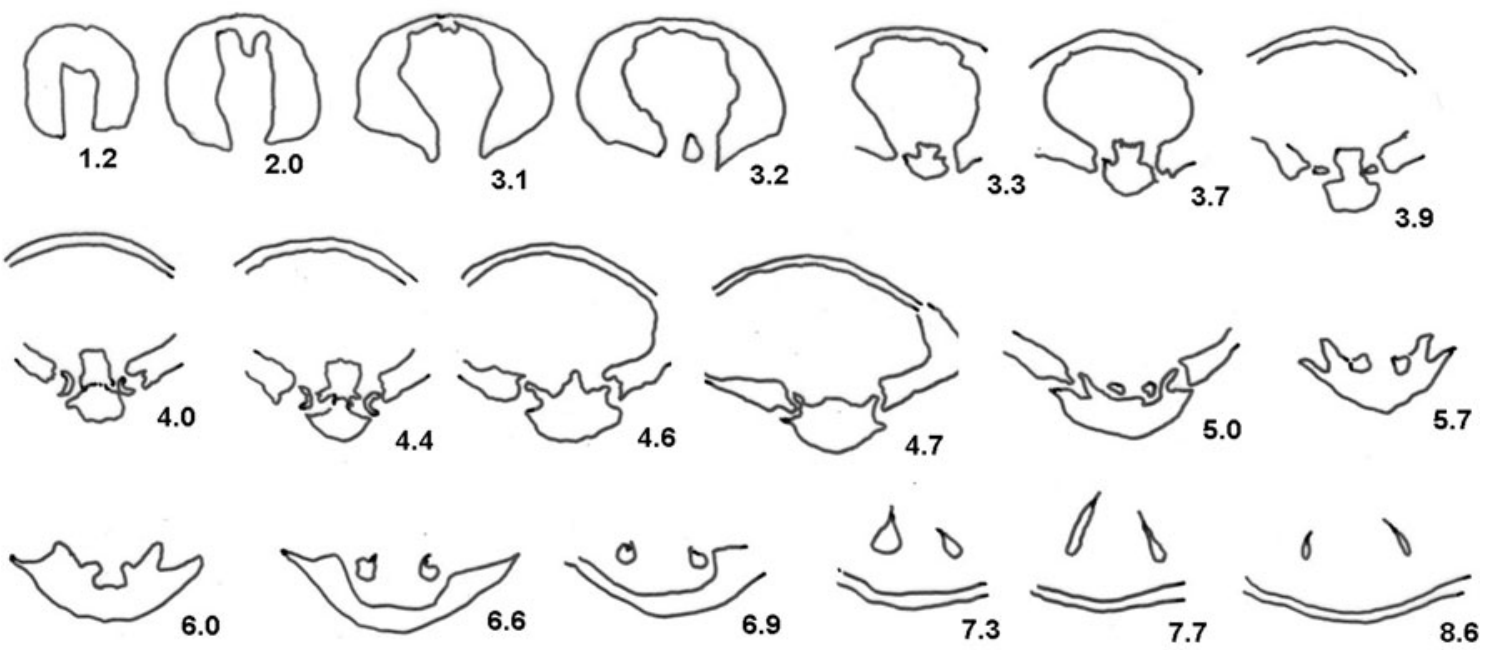

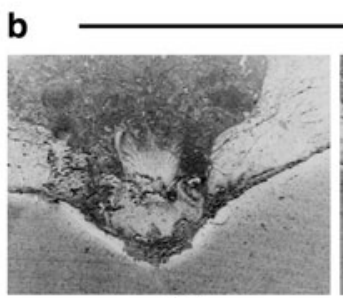

3.7

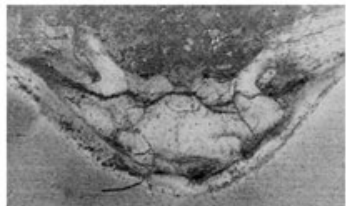

5.0

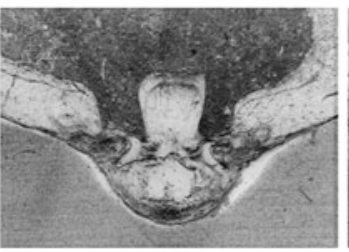

4.1

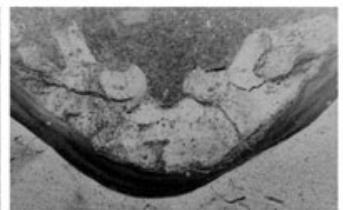

5.7

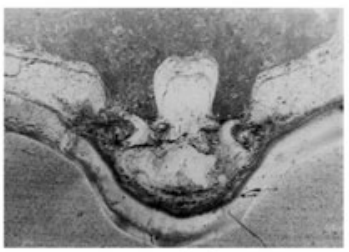

4.4

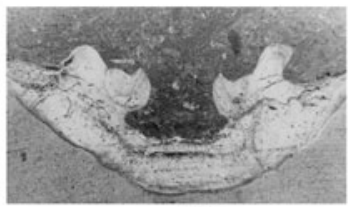

6.2

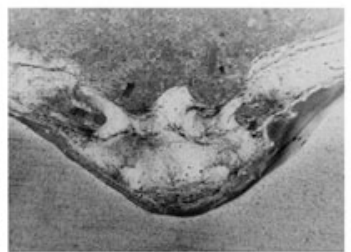

4.5

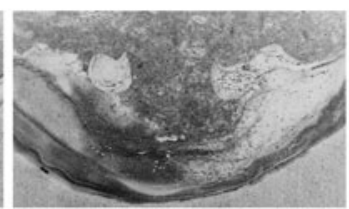

6.5
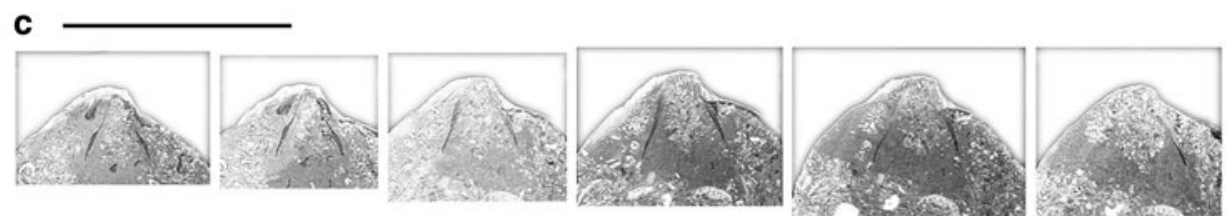

Fig. 5 Serial transverse sections of Carneithyris subregularis (Quenstedt 1871). a Specimen (length $24.7 \mathrm{~mm}$, width $22.2 \mathrm{~mm}$, thickness $12.5 \mathrm{~mm}$ ) of Eocene (Lutetian), Obere Leugangen, Fäneren area. b Same series, as figured in a, by selected micrographs. c Serial

1869 Terebratula subregularis KeFERSTEIN (sic); QuENSTEDT: 374

1871 Terebratula subregularis KeFERSTEIN (sic); QUENSTEDT: pl. 48, figs. 28-29

1878 Terebratula Kickxi Galeotti; Moesch: 7

1923 Terebratula subregularis (KeFERSTEIN) QuENSTEDT; ROLLIER: 63, 66

1923 Terebratula minor NILSSON; RolLIER: 63

1923 Terebratula rhomboidalis NiLsSON; ROLLIER: 63

1923 Terebratula cfr. rhomboidalis NiLsson; RolLIER: 66

1923 Terebratula sp. nov., cfr. ovata NiLsson; RoLLIER: 66 longitudinal sections, parallel to commissural plane. Incomplete specimen (length unknown, width $20.0 \mathrm{~mm}$, thickness $9.8 \mathrm{~mm}$ ), sections taken from dorsal valve, from left to right: 5.2, 5.0, 4.8, 4.6, 4.4, $4.2 \mathrm{~mm}$ residual thickness. Scale bar: $1 \mathrm{~cm}$

\section{Terebratula subovata SOWERBy; RolLIER: 65, 76}

Lectotype (here designated): The specimen is figured in Quenstedt (1871), pl. 48, fig. 29 by dorsal and anterior view, from "Flysch Fähnern, Schwendi", Canton Appenzell I.R., NE Switzerland. It is reproduced in dorsal, ventral, lateral and anterior view in Fig. 3a and deposited in the collection (inventory nr. GPIT/3/48/29) of the Institute of Geosciences, Eberhard Karl University, Tübingen, Germany.

Type region: Northern and north-western slopes of Fäneren Mountain, Canton Appenzell I.R., NE Switzerland. 
Glauconitic sands and sandy limestones of the "Gallensis" beds, a transitional facies between the Einsiedeln and Bürgen Formation (Eocene/Lutetian) of South-Helvetic origin.

Occurrence: Type region; E Switzerland (Einsiedeln, Oberiberg, Canton Schwyz); central Switzerland (Bürgenstock, Canton Nidwalden); Austria (Dornbirn, Hohenems, Vorarlberg); Germany (Kressenberg, Blomberg near Tölz, southern Bavaria; Grünten near Sonthofen, Allgäu).

Age: Eocene (Lutetian), according to nummulitids from samples in the collection of W.A. Ooster from the same site, deposited at NMBE.

Material: 20 specimens, used for shell measurements, six specimens for transverse and one for longitudinal serial sections.

Description-external morphology (Figs. 3, 4): Biconvex, smooth shell. Length on average 25 (range 18-31) mm, width 21 (15.5-26) mm, thickness 12 (8.5-15) mm. Outline subpentagonal, elongate oval, subrhomboidal to subcircular. Lateral and anterior margins sharp, lateral and anterior commissure generally straight, slightly curved towards the hinge line. Weathered shell surface often with a characteristic pattern (Fig. 4a). Adductor muscle scars occasionally observed on dorsal valve of internal moulds (Fig. 4b). Interarea small and concave. Apical ridges smooth. Umbo suberect. Pedicle foramen labiate, meso- or permesothyridid, small $(1-2 \mathrm{~mm}$ in diameter). Deltidial plates or symphytium not observed. Apical angle variable $\left(80^{\circ}-120^{\circ}\right)$ according to shape of outline.

Description-internal morphology (Fig. 5): Ventral valve: Umbonal cavities with massive callosities (accumulations of secondary layer often conceal structural details, Figs. 4c, d). Massive hinge teeth loosely inserted in dorsal sockets. Dorsal valve: Cardinal process conspicuous, in successive transverse sections it shows a bilobed, finely striate pit with inclining edges, distally becoming a broad, stout, almost rectangular bulb (Fig. 5b, sect. 4.1, 4.4). No median septum. Sockets semi-circular, with marked ridges. Outer hinge plates short, stout, slightly concave ventrally, tapering towards the margin of inner socket ridges; ventrally devoid of secondary callosities. Inner hinge plates absent. Crural bases straight, attached to the inner edges of outer hinge plates, medium sized, enclosed in swollen, nodular mass of callotest or appositional layers, proximally forming narrow channels. As observed in transverse section, the system of the outer hinge plate, crural base and enclosing callotest produce a comma-like symbol, where separate from outer socket ridges (Fig. 5b, sect. 4.5-6.5). Slender crura extend ventrally. Crural processes indicated by thickened tips (Fig. 5a, sect. 7.3-8.6). Loop subtrigonal. Descending lamellae extend to $25-30 \%$ of dorsal valve length. Transverse band with terminal points usually not preserved.
Discussion-history of species: Münster (1828) established Terebratula subregularis as a nomen nudum for a brachiopod from the "Thoneisenstein" and "Grünsand" of the Kressenberg near Traunstein (southern Bavaria, Germany). He was one of the first of his contemporary geologists who correctly recognized these deposits as being of Tertiary and not Cretaceous age. Gümbel (1861) used Münster's species name for the terebratulides, occurring in the Nummulitic beds of Allgäu (Germany) and central Switzerland (Bürgenstock).

Quenstedt (1868-1871), however, drew attention to Terebratula subregularis, ${ }^{1}$ which had long been known from the Alps. He figured a specimen from the Fäneren area and gave a detailed description, referring to a shell of an oval, elongated outline, usually becoming narrower anteriorly, but with the occasional tendency to become circular. He noted the typical ornamentation on shell surface, which can readily be observed in many Fäneren samples. Quenstedt also illustrated some details of the interior structure (Fig. 3b).

Ooster (1863) assigned the Fäneren terebratulides to Terebratula kickxi, an Eocene species originally described by Galeotti (1837, p. 61, pl. 4, figs. 15, 15A) from the sands of Assche (Barton Clay, Priabonian) near Brussels (Belgium). Nyst (1843, p. 335, pl. 29, fig. 4) contributed an improved figure (the one illustrated by Galeotti was probably a juvenile without specific characters), and he confirmed, as Davidson (1874) did later, the description by Galeotti. Davidson indicated the occurrence of a similar form in corresponding deposits of the Alps. Vincent (1893) provided a rough reconstruction of its internal structures showing a trilobed cardinal process, robust crura with marked crural processes, connected by a delicate transverse band and forming a short wide loop.

Moesch (1878) was obviously not aware of Quenstedt's publication and followed Ooster by listing T. kickxi among the fauna from the Nummulitic beds of Fäneren. He mentioned in addition Terebratula subalpina, a dubious taxon that Mayer had used in his publication in 1877 and later Mayer-Eymar in 1887. This author referred that name to a species allegedly erected by Münster, but without precise citation. T. subalpina was reported from the Fäneren region by Heim (1905) with reference to A. Escher' diary. We were not able to locate T. subalpina in any of the publications of Münster. Maybe Mayer confused it with $T$. subregularis. When Rollier (1923) investigated the fossil assemblage of the Fäneren area, he used a couple of Late Cretaceous species names for his determinations of the brachiopods: several taxa from Nilsson (1827), but also

\footnotetext{
$\overline{1}$ Quenstedt attributed Terebratula subregularis erroneously to Keferstein who is the editor of the journal in which Münster published the species.
} 
Terebratula subregularis (see synonymy). The general shell shape and the beak region of these forms are in fact quite similar and reflect to a certain degree the intraspecific variability of the Fäneren samples.

Besides the Fäneren area, T. subregularis was identified in the Steinbach fossil bed from the Nummulitic limestone near Einsiedeln and in the region of Oberiberg (Switzerland), as well as in coeval sediments of the Säntis nappe in Vorarlberg (Austria). According to Leupold (1966), all these fossiliferous strata are of Early Lutetian age.

Discussion-comparison with Terebratula kickxi: Vincent (1923) assigned T. kickxi to the genus Gryphus, however, a thorough revision of this species is still lacking. In a preliminary report, Bitner et al. (2007) identified it in Eocene deposits of Hungary, and stated that it is widely distributed in Europe during this epoch. We were not successful in acquiring topotype specimens for study from Belgium. T. kickxi must still be considered an ill-defined species, but may be closely related to $T$. subregularis. As long as no new data are available, we retain subregularis as a separate species, adequately described and figured by Quenstedt (1868-1871). Although the peculiar shell ornamentation should not be used on its own as a character at species level, it is a further indication of the morphology of the species. It may here be mentioned that an Eocene form in the Bavarian Alps, Terebratula picta ${ }^{2}$ sensu Schafhäut (1863), shows a very similar elongate-oval shell with an ornamental pattern reminiscent of that of $T$. subregularis.

Discussion-generic assignment: Terebratula subregularis shares common features with species like T. kickxi, T. aequivalvis and T. hilarionis. These brachiopods form a group of short-looped terebratulids. A genus which matches the general external characters of these taxa is Gryphus Megerle von Mühlefeldt 1811, typified by the Recent Anomia vitrea Born 1778. Recent to Paleogene species have been attributed to it. However, the internal features of $T$. subregularis do not favour assignment to Gryphus. In contrast to G. vitreus, the outer hinge plates in T. subregularis are not flat and show an only slight virgation. Moreover, the cardinal process of $T$. subregularis displays a much more distinctive character, and mediotest and callotest structure of the hinge plates and crural bases differ qualitatively (Fig. 6a, d).

The Fäneren species shows strong callosities in the umbonal cavities and the proximal parts of the cardinalia. Important characters are the conspicuous, persistent cardinal process (see details in the description), the slightly concave outer hinge plates, attached to medium sized crural bases which suggest that $T$. subregularis may be

\footnotetext{
${ }^{2}$ Schafhäutl was not aware that the taxon picta was preoccupied by a recent species: Anomia picta Dillwyn 1817 (now type species of Pictothyris Thomson 1927).
}

placed within the Carneithyris group. Its most representative genus is Carneithyris SAHNI 1925. Genera, like Chatwinothyris, Ellipsothyris, Magnithyris, Ornithothyris, Pulchrithyris, all established by Sahni 1925, are now considered to be variants of Carneithyris (Asgaard 1975), as well as Ogmusia COOPER 1983. Similar, but so far restricted to the Upper Cretaceous of Sweden, is Rhombaria COOPER 1983. It is noteworthy that its type species, Terebratula rhomboidalis NILSSON 1827, was one of the taxa that Rollier (1923) chose for to name the Fäneren terebratulids. A closely related genus is Giraliathyris CRAIG 2000, much resembling Carneithyris in general shell shape, and presently restricted to the Paleogene of Australia (Lee and Smirnova 2006, p. 2078-2080).

Carneithyris, essentially a Cretaceous genus, comprises representatives that crossed the $\mathrm{K} / \mathrm{T}$ boundary as demonstrated by Zelinskaya (1975). Thus, an aberrant development of the cardinal process is present also in Paleogene species whereas in contemporary species of Gryphus this character is mainly lost. The cardinal process of Carneithyris is described as highly variable, large to massive, bulbous. The published serial sections of several species of Carneithyris (Steinich 1965; Farrow \& Owen 1980; Gaspard 2002) provide a base to justify a relationship of T. subregularis with this genus. Our own sections of Carneithyris carnea (SOWERBY) display a prominent cardinal process, short stout outer hinge plates and high and straight crural bases that are in good accordance with those of T. subregularis (Fig. 6a, e, f). In conclusion, we assign the species to Carneithyris subregularis.

\section{Brachiopods related to Carneithyris subregularis}

It is not the aim of this paper to undertake a comprehensive study of these related terebratulidines, but some forms in connection with the occurrences in the Helvetic Eocene require discussion here. Some other related species have been described from different regions, such as the former Yugoslavia (Bulle and Rollet 1973), the Crimean Peninsula (Zelinskaya 1975), the Caribbean area (Cooper 1979) and elsewhere.

Terebratula aequivalvis was established by Schafhäutl 1863 (p. 129-130, 305, 311, pl. 25, fig. 1, pl. 65c, fig. 12) from the Kressenberg area in southern Bavaria (Germany) (Fig. 7c). It is an Eocene species from the Alpine Helvetic belt, lining the northern rim of the Alps along a distance of about $400 \mathrm{~km}$. Ooster (1863) cited specimens from several sites in E and NE Switzerland which he named Terebratula kickxi, but which differ distinctly from the forms described here as Carneithyris subregularis and which may belong to Schafhäutl's species (Fig. 7a, b). Schlosser (1925) confirmed and redescribed it as an equivalved shell with an approximately circular outline, a small flat, unconspicuous 

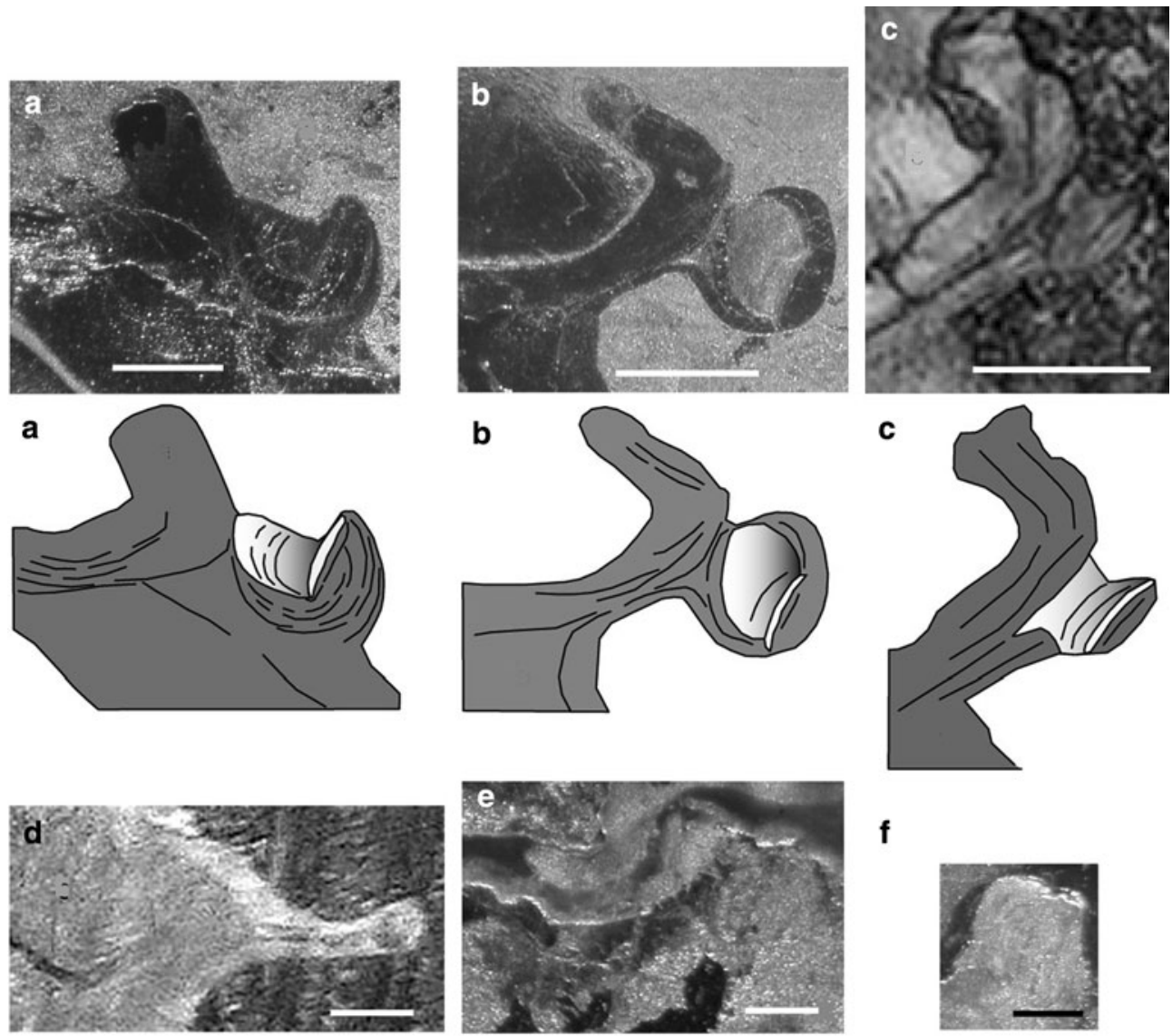

$\mathbf{f}$
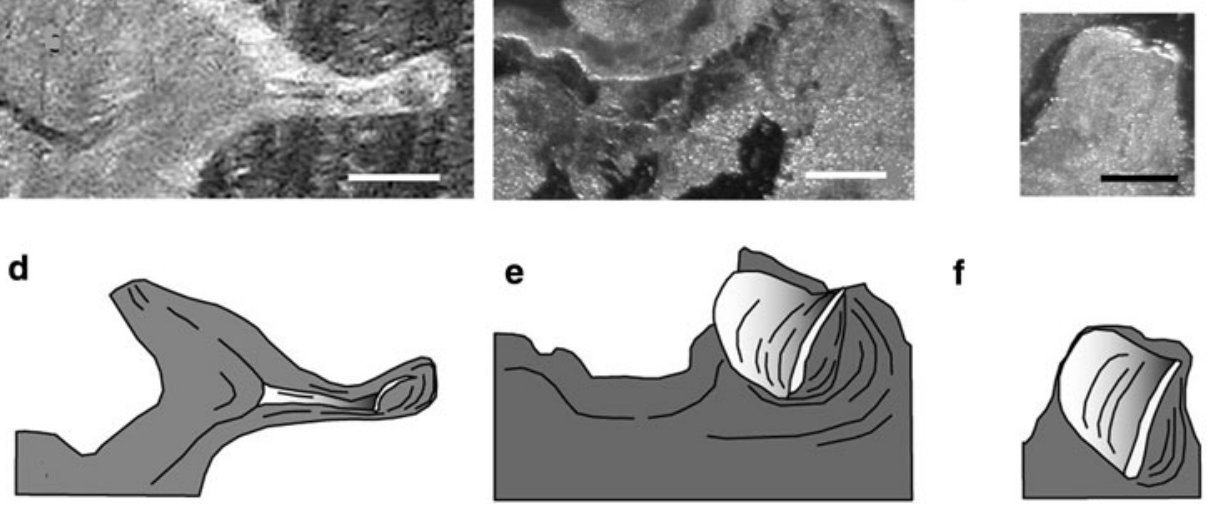

Fig. 6 Relationship between mediotest and callotest patterns in the studied terebratulidines; schemes based on particular transversal sections (not to scale). The drawings show white infillings representing crural base, gradient grey infillings representing outer hinge plate (mediotest) and dark grey infillings representing appositional layers (callotest). a Carneithyris subregularis (QUENSTEDT 1871) (section $6.0 \mathrm{~mm}$ ). b Carneithyris aequivalvis (Schafhäutl 1863)

beak and a minute pedicle foramen. It is a distinctive brachiopod, but Gümbel (1865, p.143, 144) classified it as a conspicuous variant of $T$. subregularis. Quenstedt (1868-1871, p. 374-375, pl. 48, fig. 30-34) noted the strange homeomorphy with the Liassic Cincta numismalis, thus resembling a terebratellidine brachiopod. T. aequivalvis also resembles Eogryphus Hertlein and Grant 1944, a long-looped Eocene genus from California (Cooper 1983, p. 245).

Topotypes of $T$. aequivalvis occur in the "RoterzSchichten" (now the Frauengrube subformation of Ypresian age in the lithological successions revised by (section $4.0 \mathrm{~mm}$ ). c Carneithyris hilarionis (DAVIDSON 1870) (section $2.9 \mathrm{~mm}$ ). d Gryphus vitreus (BoRN 1778), section $3.25 \mathrm{~mm}$ of a specimen (length $25.5 \mathrm{~mm}$, width $22.4 \mathrm{~mm}$, thickness $13.7 \mathrm{~mm}$ ), Holocene, Adriatic Sea. Carneithyris carnea (Sowerby 1812), section $6.6 \mathrm{~mm}(\mathbf{e})$ and $7.6 \mathrm{~mm}(\mathbf{f})$ of a specimen (length $27.4 \mathrm{~mm}$, width $23.2 \mathrm{~mm}$, thickness $16.4 \mathrm{~mm}$ ) from the Late Campanian, Harmignies near Mons (Belgium). Scale bars: $1 \mathrm{~mm}$

Rasser and Piller 1999a). This reddish sediment contains limonite with an iron content of 15-17\% (Hagn et al. 1992). The origin of iron is not clear, but presumably was due to primary impregnation during sedimentation processes (Friebe 1995). Whether the development of large-sized specimens was related to the ferrogenous facies or some other unknown factors is an open question.

According to Herb (1962) the stratigraphical position of the Swiss ocurrences of $T$. aequivalvis seems to be confined to the Early Eocene (Ypresian). A difficulty exists, however, in the isolated and complex tectonic positions of the 
Fig. 7 Carneithyris aequivalvis (SChafhäutl 1863). a Specimen in dorsal, lateral and anterior view from the Ypresian (Eocene) of Höch-Gütsch near Oberiberg, Canton Schwyz, Switzerland (PIMUZ 27583). b Specimen in dorsal view from the Ypresian subalpine

"Randflysch-Zone" of FlybachTobel above Weesen, Canton St. Gallen, Switzerland (PIMUZ 27584). c Specimen in dorsal, lateral and anterior view from the Frauengrube-Subformation ("Roterz-Schichten") of its type region Kressenberg, Southern Bavaria, Germany (PIMUZ 20013). d Selected serial transverse sections of a specimen (length $31.6 \mathrm{~mm}$, width $32.2 \mathrm{~mm}$, thickness $18.2 \mathrm{~mm}$ ) from the same age and locality as the one figured in a. Carneithyris aff. aequivalvis (SCHAFHäUtL 1863). e Specimen in dorsal view from the Lutetian of Surbrunnen/Gschwänd near Oberiberg, Canton Schwyz, Switzerland (PIMUZ 27585). f Specimen in dorsal view from the Lutetian of the Lithothamnian reef near Aebiskraut/Eggli, Canton Appenzell I.R, Switzerland (collection H. Sulser). All scale bars: $1 \mathrm{~cm}$
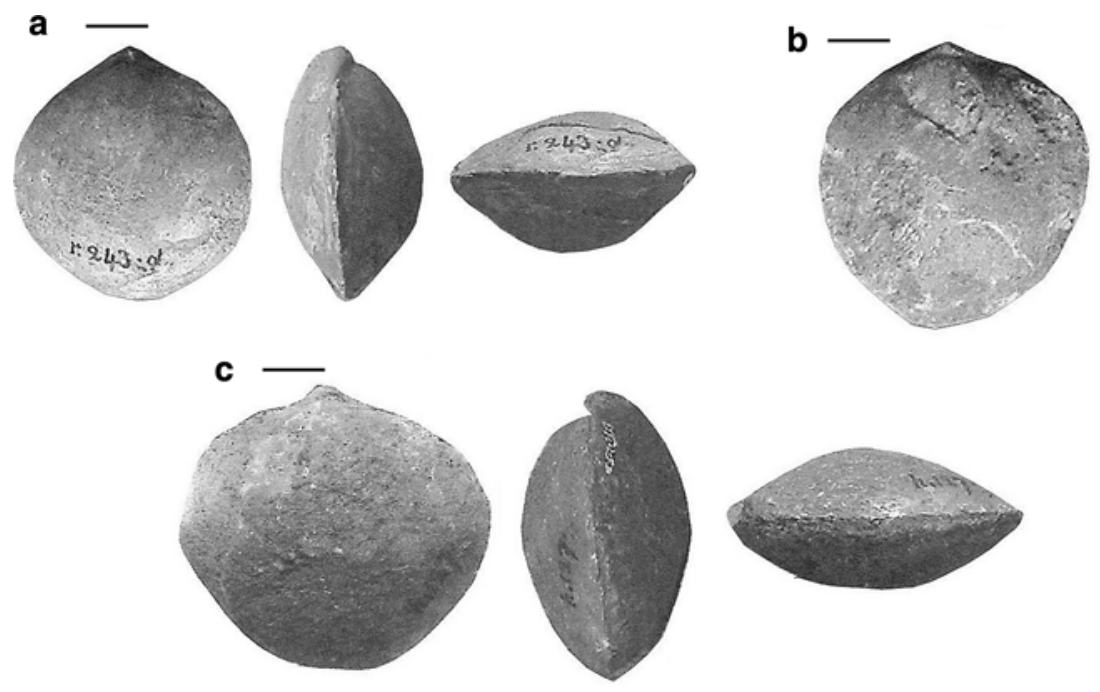

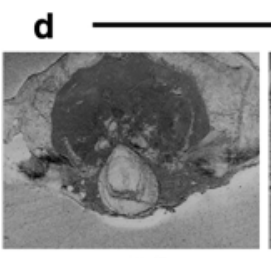

2.1

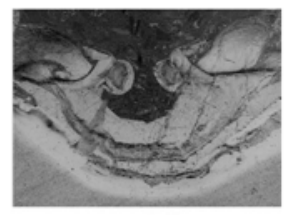

3.6

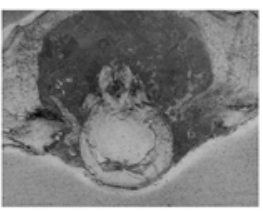

2.3

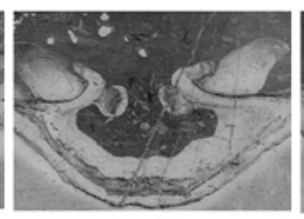

4.0

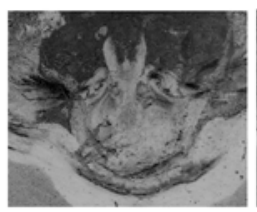

2.5

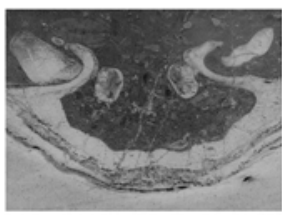

4.4

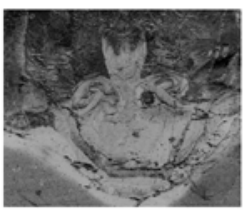

3.0

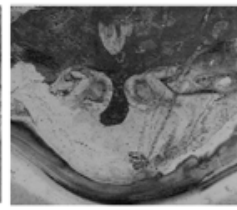

3.2
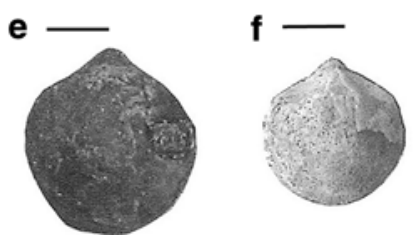

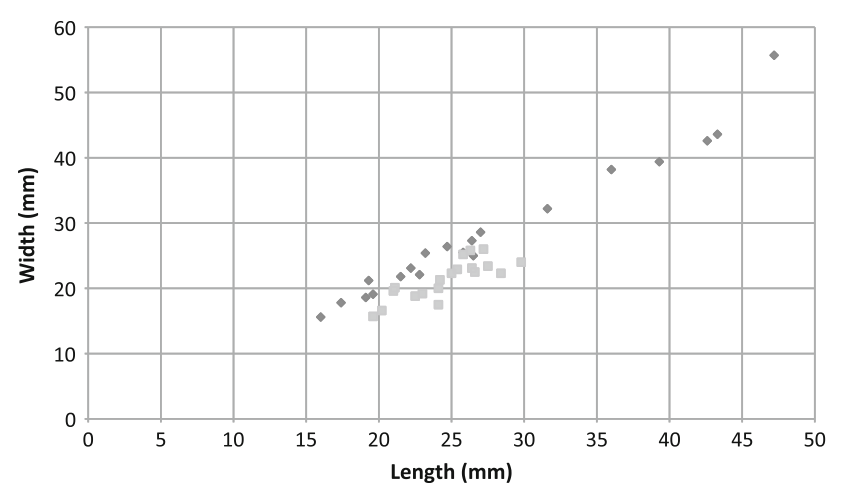

$\checkmark$ Carneithyris aequivalvis Carneithyris subregularis

Fig. 8 Length-width plot of 20 specimens of each Carneithyris subregularis and Carneithyris aequivalvis. In C. subregularis length exceeds or rarely equals width (mean length/width ratio 1.15). In C. aequivalvis length equals width or is slightly less (mean length/width ratio 0.97 ) widespread South-Helvetic Paleogene strata and the reconstruction and correlation of stratigraphical successions, even over comparatively short distances. The same inconsistency concerns the facial variations of these deposits (Leupold 1966; Menkveld-Gfeller 1997; Rasser and Piller 1999a, b; Friebe 2007).

A comparative analysis of the shell dimensions at different stages of growth of both $T$. aequivalvis and G. subregularis indicates the similarity of both species (Fig. 8). This is also supported by preliminary sections (Fig. 7d). They clearly show that T. aequivalvis belongs to the subregularis group. The hinge plates are robust, nodular and ventrally convex with no trace of virgation (Fig. 6a, b). Its cardinal process is very similar to that of Carneithyris subcardinalis Sahni 1925 which the author originally erected as the type species of Chatwinothyris. Some intermediate forms, in external aspect varying 
Fig. 9 Carneithyris hilarionis (DAVIDSON 1870). a Specimen in dorsal, ventral and anterior view from the Lutetian of Ciupio San Giovanni Ilarione, Verona, Italy, also figured in Fabiani 1913 (pl. 1, figs. 15, 15a, 15b) (MGPD 11698). b Serial transverse sections of a specimen of same age and locality as the one in a, showing different stages of a trilobate cardinal process (see arrow in section 2.6). All scale bars: $1 \mathrm{~cm}$

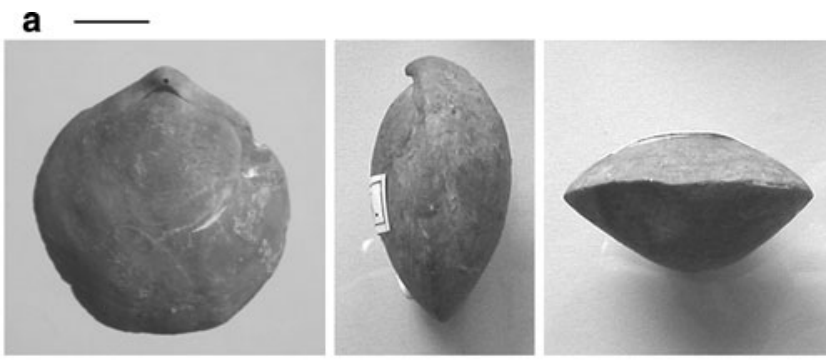

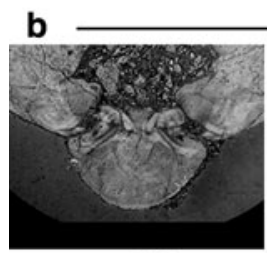

2.2

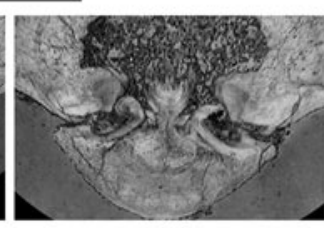

2.4

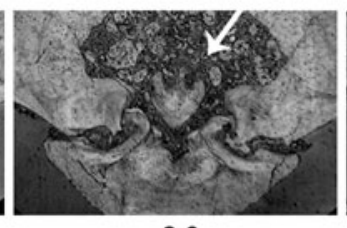

2.6

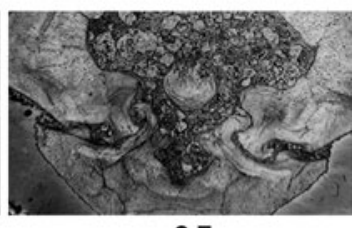

2.7

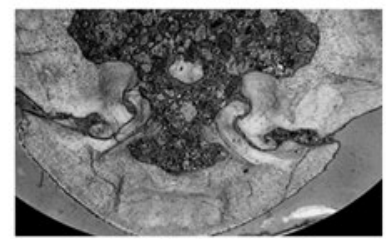

2.9

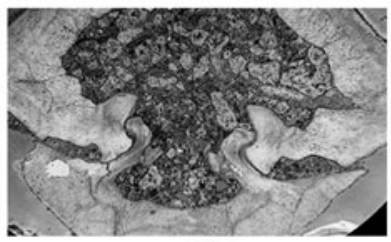

4.3

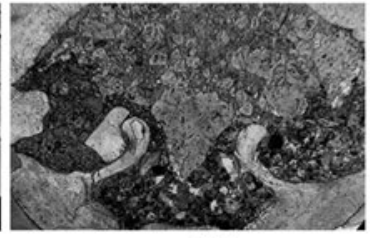

4.5 between aequivalvis and subregularis, were named Carneithyris aff. aequivalvis (Fig. 7e, f).

Terebratula hilarionis (Davidson 1870, p. 401-402, pl. 17, figs. 4, 5) occurs in a Lutetian volcanic tuff from San Giovanni Ilarione in the Verona province of Italy (type locality). It was also reported from Veneto, Trentino, Friaul, Hungary, Croatia and the Caucasus (Bayan 1870; Oppenheim 1894, 1896; Vogl 1912; Fabiani 1913; Dainelli 1915; Altichieri 1992, Fig. 9a). It rapidly became a frequently cited species in the literature, but the taxon was applied rather uncritically to Eocene occurrences in Bavaria (Schlosser 1925), Vorarlberg (Böhm 1936), the region of Salzburg (Schultz 1998) and elsewhere. The species has also been identified in several outcrops from Spain (unpublished data of one of us, D.G.-R.). Davidson (1870) and later Fabiani (1913) characterized T. hilarionis by its smooth, biconvex, somewhat variably shaped, generally circular shell of equal length and width $(28-33 \mathrm{~mm}$ each), a maximum width at half shell length, and 15-17.5 mm thickness. The subspecies Terebratula hilarionis novalensis from Contrà Novella di Novale (Vicenza province), established by Fabiani (1913), is somewhat longer and thicker, the valves more swollen, the beak less prominent, and without "a trace of sinus". It probably falls within the variability of the type species.

Transverse serial sections, constructed by M.A. Bitner and housed at the Department of Geoscience of the University of Padova, were made available by courtesy of M.A. Bitner (Fig. 9b). The cardinal process of T. hilarionis is much like that of $T$. aequivalvis, protuberantly trilobed (Fig. 6b, c). There is no doubt that this species, tentatively assigned with Gryphus, represents a further candidate for placement in Carneithyris. Carneithyris hilarionis is not known from the Eocene of Switzerland.

\section{Terebratulina s.l. (form 1 and 2) (Fig. 10)}

Superfamily Cancellothyridoidea Tномsоn 1926

Family Cancellothyrididae Thomson 1926

Subfamily Cancellothyridinae Thomson 1926

Genus Terebratulina D'ORBIGNY 1847

Type species Anomia retusa LinNaeus 1758

Material: All specimens were embedded in the matrix, partly with traces of calcitic cement on the shell surface. Dissection from the matrix was not attempted. Due to the poverty of material, descriptions were limited to general shell characters, like size, outline and ornament. Internal structures remain unknown. The genus Terebratulina is used here in a broad sense (Terebratulina s.l.). As our material did not enable a detailed description; open nomenclature is used.

Description: Terebratulina s.l. form 1, from Langwald (Fig. 10a). Capillate ventral valve $(13 \mathrm{~mm}$ long, $12 \mathrm{~mm}$ wide) of rounded outline, with a wide apical angle, maximal width at about $2 / 3$ shell length. Fine, straight and sharp capillae $(0.5 \mathrm{~mm}$ distance at half shell length, $0.8 \mathrm{~mm}$ at the front) radiate regularly from the umbo to the lateral and anterior margin. Terebratulina s.l. form 2, from ChlusHöllflätschen (Fig. 10b). Dorsal valve (21 mm long, 
Fig. 10 Terebratulina s.l. a form 1, specimen in ventral view from the Lutetian of Langwald, Fäneren region, NE Switzerland (collection P. Kürsteiner). b Form 2, specimen in ventral view from the Lutetian of Chlus-Höllflätschen, Fäneren region, NE Switzerland (NMSG P. 1008)

c "Terebratula pentagonalis" as figured in Phillips (1829). All scale bars: $1 \mathrm{~cm}$
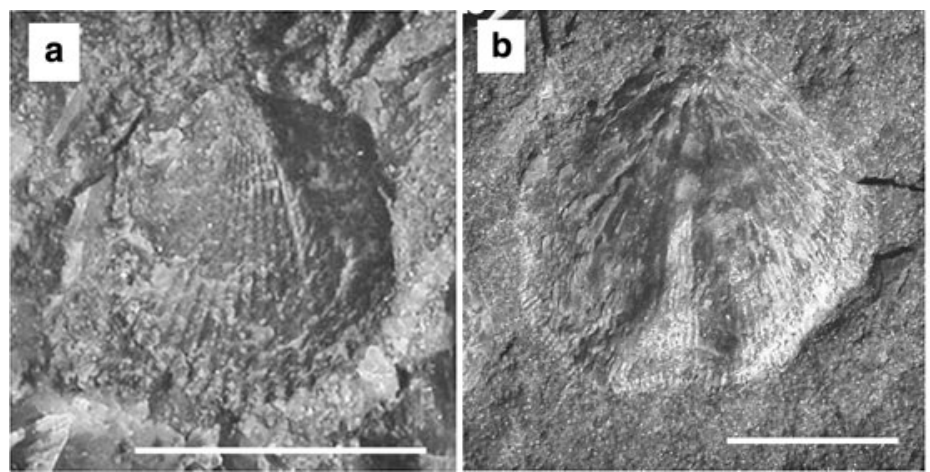

C

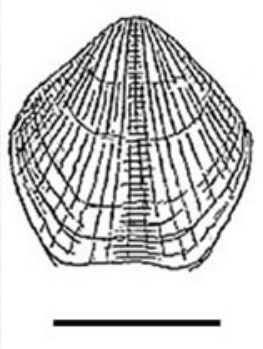

$21 \mathrm{~mm}$ wide) of subpentagonal outline with large, possibly rimmed pedicle opening and partly branching capillae. Very narrow median depression, originating at the hinge line and constantly spreading towards the front, $7 \mathrm{~mm}$ wide at the anterior margin. This depression is marked by two lateral folds. Additional and somewhat weaker folds are developed on both sides of the valve.

Discussion: Terebratulina-like forms from the Fäneren region have never been figured, but were listed by Moesch (1878). He referred them to species that were established for the Paleogene of Einsiedeln: Terebratulina pellati (Mayer 1877, p. 26, pl. 1, figs. 8, 9) and T. tallavignesi (Mayer 1877). The latter is a new name for the dubious Terebratula Defrancii Brongniart, figured in Leymerie (1846, pl. 15, fig. 12). These species, together with others, like Terebratulina subtriangula MAYER 1877 (p. 27, pl. 1, fig. 10), Terebratula tenuistriata LEYMERIE 1846 (p. 363, pl. 15, fig. 11), Terebratula capillata SCHAFḦ̈UTL 1863 (pl. 65c, figs. 3, 4) and Terebratula striatula SOWERBy 1829 (depicted as Rhynchonella striatula in Schafhäutl 1863, pl. 25, fig. 10), are very similar. The whole group is characterized by capillate shells of $10-15 \mathrm{~mm}$ length. Bitner (2000) showed that at least some of these taxa reflect intraspecific variation and cannot claim separate species status (see synonymy therein). Terebratulina s.l. form 1 may fall within this group.

Rollier (1923) referred a probably single specimen from the Fäneren fauna to Terebratula pentagonalis PHILLIPS (1829, p. 91, pl. 1, fig. 17) from the "White Cretaceous" of Yorkshire (Fig. 10c). Phillips' species compares well with Terebratulina s.l. form 2 which is in good accordance with Terebratula multistriata sensu Ooster (1863, pl. 10, fig. 6) from Gschwendtobel (region of Oberiberg, Switzerland). Terebratula multistriata was originally described by Dunker (1851, p. 128) from the Tertiary in northern Germany.

Late Cretaceous and Paleogene Terebratulina species obviously display many common external features. The uncommon character of a median depression can be seen on an unnamed Terebratulina from the Upper Cretaceous of Ross Island, Antarctica (Owen 1980).
Similar forms of Terebratulina s.l. discussed here are known from the Eocene of Vorarlberg, Austria.

A name frequently encountered in museum collections and in the Eocene brachiopod literature of the Alps in Germany, Austria and Switzerland (Böhm 1936; Hagn and Schmid 1988; Mayer 1877; Mayer-Eymar 1887) is Terebratulina parisiensis DeshaYes 1860 to 1864 . Schlosser (1925) introduced the name for the most common Terebratulina in the Bavarian Alps without doubt. Deshayes figured T. parisiensis from the Paris basin in 1860, before he described it in 1864 . He had doubts about separating it specifically from T. tenuistriata (LEYMERIE) and T. striatula (Sowerby). Apart from T. parisiensis, Deshayes established T. tenuiplicata and commented on Baudon's (1855) species: T. Putoni, T. tenuilineata and T. squamulosa. All these brachiopods are rare and are of very small dimensions (length up to $5 \mathrm{~mm}$ ), except $T$. parisiensis with $10 \mathrm{~mm}$ length and $9 \mathrm{~mm}$ width. Cossmann and Pissarro (1910 to 1913, pl. 62) figured most of these species side by side for direct comparison. The generalized taxon parisiensis, frequently used uncritically for occurrences in Alpine Eocene sites, should be abandoned.

The life style of Terebratulina in the studied area can be related to remarks by Elliott (1947), briefly summarized here. Elliott identified the taxonomic problems surrounding the Eocene Terebratulina species and questioned the reasons that hamper reliable determinations. He emphasized the great number of juveniles together with the relative rarity and the general lack of significant characters. Moreover, in this brachiopod group, knowledge of internal structures is rather poor and-where known-poorly differentiated and diagnostically irrelevant. Terebratulina seems to have retreated to spatially discontinuous, small groups in changing habitats with reduced opportunities of settlement, because of competition by better adapted benthic organisms increased. The development of stable populations was thus impeded, and scattered individuals from geographically distant and geologically incoherent areas appear little differentiated. For Terebratulina the definition of a "true" species in a conventional manner is at 
best uncertain. These difficulties were also briefly discussed by Barczyk (1973) and Fuchs (1973).

\section{Palaeoecology}

Carneithyris subregularis is characterised by a narrow pedicle foramen, and internally, massive callosities are accumulated in the posterior part of the shell. The increase of weight may have facilitated its stabilisation with a small and short inert pedicle, or even when the animal might have adopted a free-lying habit (a similar situation has been reported by Álvarez and Emig 2005 for the morphologically similar terebratulinid Gryphus vitreus), a necessity on a seabed with reduced opportunities of fixation, such as those where the suitable substrate is mainly unconsolidated sediments (Curry 1981; Richardson 1981; Endo 1989). Overall, the morphology of Carneithyris subregularis thus suggests a specialised life habit on soft substrates (Richardson et al. 2007). A secondary free-living habit, inferred in terebratulides displaying posteriorly thickened shells was described by Surlyk (1972). He compared the attachment strategies of these brachiopods to the substrate with a "self-righting tumbler", since the thickening shifts the centre of gravity to the posterior part, maintaining the anterior commissure away from the seabed. Terebratulides belonging to this ecological group appear to share, besides thickening of posterior area, a number of common characters, like narrow to pinhole pedicle foramina, distinct beak ridges, smooth shell surfaces, a strongly biconvex lateral profile and marked muscle impressions. Internally, the cardinal processes are usually protuberant, either trilobed, cup-shaped or bulb-shaped, and the dorsal and diductor muscle impressions are deeply incised. Examples of terebratulidines bearing these characters include some species of Telothyris (Alméras and Moulan 1982) and Uralella jani-maniensis (Makridin 1964); while several examples of terebratellidines sharing these features are discussed in Mackinnon et al. (1993) and Hiller and Mackinnon (2000). A well-known example of a brachiopod specialising in soft substrates is Neothyris lenticularis (Deshayes 1839). Adult individuals of this species may become free living when their shells attain a size too large for the original holdfast that served as a settlement for the larvae. It is a remarkable observation that not only these shells seem strong enough to withstand currents up to 3 knots, but also there appears to be a correlation between the density of Neothyris populations and the turbulence conditions (Neall 1970).

It is interesting to note that for the Carneithyris group it is evident that indivuduals having remained in the same habitat there was little change in their morphological characters. It is likely that they shared the same way of life.
Representatives of these genera display cardinal processes which, otherwise rare in terebratulidines, are quite polymorphic as regards their myophores, which are massive, high and hypertrophically developed (often trilobed) in Carneithyris (Asgaard 1975; Farrow and Owen 1980; Gaspard 2002) and forming a protuberant cup in Giraliathyris (Craig 2000). Carneithyris subregularis too shows a cardinal process of a characteristic shape (see details in the description). The peculiar variability of the cardinal process as seen in these brachiopod taxa may be no more than a strategy to enlarge the surface of attachment of strong diductor muscles, related to the thickened and overloaded parts of the shell, achieved in adult ontogenetic stages. Asgaard (1975) noted a variability of the cardinal process in Carneithyris which she attributed to ontogeny, and Boullier et al. (1986) and Álvarez and Brunton (2008) illustrated ontogenetic changes of the cardinal process in Gryphus vitreus, passing from a flat pectinate cardinal process-common in many adult terebratulidines-to a prominent pronounced and trilobed one. In these cases where the cardinal process is not a diagnostic character, it might act as a morphological element of functionality.

Quite a different strategy of adaptation to a fine-grained substrate was suggested for the varied forms of Terebratulina s.l. These small pediculate brachiopods were probably attached to soft sediment by root-like, divided pedicles (Curry 1981). As commented before, it is possible that isolated specimens of Terebratulina were distributed over long distances, so that occasional occurrences are more or less accidental. There is, however, no clear biostratinomic evidence for the rarity of the taxon, and instrinsic taphonomic factors may have thus influenced its abundance. Juvenile representatives of Terebratulina in the Upper Eocene (Priabonian) of NE Italy, presumably having lived in a similar manner, were reported by Bitner and Dieni (2005).

\section{Conclusions}

In the past, palaeontological research of the Eocene in the South-Helvetic Alps of Switzerland predominantly focussed on larger Foraminifera like Nummulites and Assilina. These are the most useful fossils for correlating successions where their tectonic coherence is frequently disturbed. Other fossil groups have been neglected to date despite the fact that many sites in the Alpine Eocene are quite fossiliferous. New sampling in the study area and a survey of the collections of Natural History Museum of Bern yielded the following fossils: brachiopods, bivalves (ostreids, pectinids, cardiids, arcids, spondylids, pinnids), gastropods (naticids, scalariids, rostellariids), irregular echinoids, crabs, shark teeth, serpulids, and nautilids. A modern revision of these, however, is still pending. 
The brachiopods represent only a small group and they seem to be restricted to the terebratulidines: Carneithyris subregularis and Carneithyris aequivalvis belonging to the terebratuloids and some still insufficiently defined forms of Terebratulina s.l. belonging to the cancellothyridoids. A better knowledge of the Paleogene representatives of the genus Carneithyris, that became dominant in Cretaceous, is of particular interest. The studied species of Carneithyris show massive accumulations of callosities, which may be the prerequisite for adults to acquire a free-lying mode of life.

In the descriptions presented in this paper we included observations of particular internal structures where the appositional layers (callotest) can be detected. Variations in mediotest and callotest patterns (Cox and Middlemiss 1978; Radulović 1991; Tchorszhevskiy 1993; MotchurovaDekova et al. 2009; García-Ramos 2009) are of potential diagnostic value for the improved taxonomy of these groups. Future work may indeed contribute to a reassessment of the now available genera by utilizing these types of criteria.

Acknowledgments Relevant material from diverse museum collections was kindly made available by Dr. Toni Bürgin (NMSG), Dr. Georg Friebe (Inatura), and Dr. Heinz Furrer (PIMUZ). Prof. Igieno Dieni and Dr. Mariagabriella Fornasiero, Department of Geosciences, University of Padova, Italy, made available brachiopods of the collection R. Fabiani. Dieter Gschwend (Sonthofen) generously lent brachiopods from his private collection for comparative purposes. Dr. Michael Soom (Heimiswil) prepared one of the figures, and Peter Vollenweider (NMBE) shot the photos of the specimen which was figured by Ooster 1863. Philipe Havlik, Institute of Geosciences, Eberhard Karl Universtity Tübingen, identified Quenstedt's specimen, designated as lectotype, and Wolfgang Gerber made the photos. Critical reviews and useful comments by Maria Aleksandra Bitner, Alfrèd Dulai, and by the associate editor David A.T. Harper and the editor Daniel Marty considerably improved the manuscript. Dr. Vladan Radulović, Belgrade, Dr. Sandra Carlson, Davis, Dr. Fernando Álvarez, Oviedo, and Dr. Neda Motchurova-Dekova, Sofia, are warmly acknowledged for providing relevant literature. We thank all these persons for their manifold suggestions and tips, which finally made the publication of our study possible.

\section{References}

Alméras, Y. \& Moulan, G. (1982). Les Térébratulidés liasiques de Provence. Paléontologie, biostratigraphie, paléoécologie, phylogénie. Documents des Laboratoires de Géologie de Lyon 86, $365 \mathrm{pp}$.

Altichieri, L. (1992). Aggiornamento sulla fauna dei brachiopodi delle Venezie. Memorie di Scienze geologiche, 44, 211-227.

Álvarez, F., \& Brunton, C. H. C. (2008). On the reliability of reconstructing and comparing brachiopod interiors and their morphological variations based solely on serial sections. Proceedings of the Royal Society of Victoria, 120, 58-74.

Álvarez, F., \& Emig, C. C. (2005): Brachiopoda. In Álvarez, F., Emig, C. C., Roldán C. \& Viétez, J. M.: Lophophorata, Phoronida, Brachiopoda. In: Ramos, M. A. et al. (Eds.), Fauna
Ibérica (Vol. 27, pp. 57-177). Madrid: Museo Nacional de Ciencias Naturales.

Asgaard, U. (1975). A revision of Sahni's types of the Brachiopod subfamily Carneithyridinae. Bulletin British Museum (Natural History), Geology, 25, 319-365.

Bachmann, I. (1867). Über das Vorkommen einer Lingula in der Meeresmolasse. Mitteilungen der naturforschenden Gesellschaft Bern, 260-261.

Barczyk, W. (1973). Brachiopods Terebratulina delheidi Vincent in the Nummulite Eocene of the Tatra Mts. Acta Geologica Polonica, 23, 491-497.

Baudon, A. (1855). Notice sur quelques térébratules du calcaire grossier non décrites jusqu'à ce jour. Société Académique d'Archéologie. Sciences et Arts du Département de l'Oise, Bulletin 2, 687-691.

Bayan, M. F. (1870). Sur les terrains tertiaires de la Vénétie. Bulletin de la Société géologique de la France, série, 2(27), 444-486.

Bitner, M. A. (2000). Lower Eocene (Middle Ilerdian) brachiopods from the Campo region, central Pyrenees, NE Spain. Revista Española de Paleontología, 15, 117-128.

Bitner, M. A., \& Dieni, I. (2005). Late Eocene brachiopods from the Euganean Hills (NE Italy). Eclogae geologicae Helvetiae, 98, 103-111.

Bitner, M. A., Dulai, A. \& Galácz, A. (2007). Eocene brachiopods from the Bakony Mts., Hungary-a preliminary report. 10. Magyar Óslénytani Vándorgyúlés 2007, Budapest, May 24-26. (Abstract 10-11).

Böhm, J. (1936). Zusammenstellung der mitteleocänen Flora und Fauna Vorarlbergs. Zeitschrift der deutschen geologischen Gesellschaft, 88, 497-500.

Born von, I. (1778). Index rerum naturalium Musaei Caesarei Vindobonnensis. Part I. Testacea. Verzeichnis der natürlichen Seltenheiten des K.K. Naturalien-Cabinets zu Wien, 1 Schalentiere. Vindobonae. $458 \mathrm{pp}$.

Boullier, A., Delance, J-H., Emig, C. C., d'Hondt, J-L., Gaspard, D. \& Laurin, B. (1986). Les populations actuelles de Gryphus vitreus (Brachiopoda) en Corse. Implications paléontologiques. In P. R. Racheboeuf \& C. C. Emig (Eds.), Les brachiopods fossils et actuels (Vol. 4, pp. 179-196). Biostratigraphie du Paléozoïque.

Büchi, U. P. (1955). Zur Geologie der Oberen Meeresmolasse von St. Gallen. Eclogae geologicae Helvetiae, 48, 257-321.

Bulle, J., \& Rollet, A. (1973). Une nouvelle espèce de brachiopode de l'éocène superieur de Macedoine Yougoslave. Annales scientifiques de l'Université de Besançon (Géologie), ser, 3(20), $111-119$.

Cooper, G. A. (1979). Tertiary and cretaceous brachiopods from Cuba and the Caribbean. Smithsonian Contributions to Paleobiology, $37,44$.

Cooper, G. A. (1983). The Terebratulacea (Brachiopoda), Triassic to recent: A study of the brachidia (loops). Smithsonian Contributions to Paleobiology, 50, 445.

Cossmann, M. \& Pissarro, G. (1910-1913). Iconographie complète des coquilles fossiles de l'Éocène des environs de Paris. 2nd vol.: Scaphopodes, gastropodes, brachiopodes, céphalopodes et supplément. Paris, 65 plates and alphabetic table.

Cox, M. M., \& Middlemiss, F. A. (1978). Terebratulacea from the Cretaceous Shenley Limestone. Palaeontology (London), 21, 411-441.

Craig, R. S. (2000). The Cenozoic brachiopods of the Carnarvon basin, western Australia. Palaeontology, 43, 111-152.

Curry, G. B. (1981). Variable pedicle morphology in a population of the Recent brachiopod Terebratulina septentrionalis. Lethaia, 14, 9-20.

Dainelli, G. (1915). L'Eocene friulano (p. 721). Firenze: Monografia geologica e paleontologica. Memorie Geografiche. 
Davidson, T. (1870). On Italian tertiary Brachiopoda. Geological Magazine, 7, 359-370, 399-408, 460-466.

Davidson, T. (1874). On the Tertiary Brachiopoda of Belgium, etc. Geological Magazine, 11, 150-158.

de C Sowerby, J. (1829). The mineral conchology of Great Britain. Richard Taylor, London, vol. 6, 230 pp. (1826-1829).

Decrouez, D. \& Menkveld-Gfeller, U. (2003). Leupold's Schläfli Preisschrift 1939-Studien zur Nummulitenstratigraphie des alpinen und westeuropäischen Alttertiärs. Revue de Paléobiologie, 5,301 .

Deshayes, G.-P. (1839). Térébratules de la Nouvelle Zélande. Revue Zoologique, par la Société Cuvierienne, 2, 359.

Deshayes, G.-P. (1860-1864). Description des Animaux sans vertèbres découverts dans le Bassin de Paris comprenant une revue générale de toutes les espèces actuellement connues. J.-B. Baillière et Fils, Paris, atlas (1860), texte (1864), 986 pp.

Dunker, W. (1851). Über einige neue Versteinerungen aus verschiedenen Gebirgsformationen. Palaeontographica 1/3.

Egger, H., \& Oberhauser, R. (2007). Kalkiges Nannoplankton aus der Ofterschwang-Formation (Cenomanium) des Fänerenspitzes (Appenzell, Schweiz). Jahrbuch der Geologischen Reichsanstalt Wien, 147, 353-355.

Elliott, G. F. (1947). Distribution des brachiopodes en espèces et ses causes, illustrée par les Térébratulinidés de l'Éocéne de l'Europe occidentale. Bulletin de la Société géologique de France, s., 5(17), 67-80.

Endo, K. (1989). Growth and life mode of a Pleistocene brachiopod, Kikaithyris hanzawai (Yabe). Palaeontological Society of Japan, Transactions and Proceedings, 156, 286-290.

Eugster, H. (1931). Exkursion ins Fähneren-Gebiet. In: Ludwig, A., Eugster, H. \& Bächler, E. (Eds.), Berichte über die Exkursion der Schweizerischen Geologischen Gesellschaft im st. gallischappenzellischen Molasseland, im Fähneren- und Wildkirchligebiet (Vol. 24, pp. 125-157). Eclogae geologicae Helvetiae.

Eugster, H., Forrer, M., Fröhlicher, H., Kempf, Th., Schlatter, L., Blaser, R., et al. (1982). Geologischer Atlas der Schweiz 1:25000: Blatt 1115 Säntis. Geologische Kommission: Schweiz.

Fabiani, R. (1913). I Brachiopodi Terziario del Veneto. Notize sommarie. Accademia scientifica Veneto-Trentino-Istriana, Atti $6,129-132$.

Farrow, G. E., \& Owen, E. F. (1980). Shallow-water Cretaceous brachiopods from Rockall Bank, North Atlantic. Palaeontology, $23,463-470$.

Friebe, J. G. (1995). Der Nummulitenkalk von Haslach und sein geologischer Rahmen. Dornbirner Schriften, 18, 102-115.

Friebe, J.G. (2007). Geologie der österreichischen Bundesländer. Vorarlberg. Wien: Geologische Bundesanstalt 174 pp., Helvetikum 67-84.

Fuchs, H. (1973). Beitrag zur Kenntnis der Brachiopoden aus der Umgebung Klausenburg (Cluj). Földtani Közlöny, Bulletin of the Hungarian geological Society, 104, 133-135. in Hungarian, German summary.

Galeotti, M. H. (1837). Mémoire sur la constitution géognostique de la province de Brabant. Mémoires couronnées par l'Académie royale des sciences et belles-lettres de Bruxelles, 12, 192.

García-Ramos, D. (2009). Relevencia en Sistemática del estudio mediante secciones seriadas del cardinalio de los Terebratuloidea y Loboidothyridoidea (Brachiopoda) cretácicos. Boletín de la Asociación Cultural Paleontológica Murciana, 6, 34-72.

Gaspard, D. (2002). Les brachiopodes de la craie blanche de Meudon (Campanien supérieur) de la collection d'Orbigny (MNHN, Paris). Comptes-Rendues Palevol, 1, 573-585.

Greppin, J. B. (1870). Description géologique du Jura bernois et quelques districts adjacents. Beiträge zur geologischen Karte der Schweiz, 8, 357.
Gümbel, C. W. (1861). Geognostische Beschreibung des bayerischen Alpengebirges und seines Vorlandes (p. 950). Gotha: Justus Perthes.

Gümbel, C. W. (1865). Die Nummuliten-führenden Schichten des Kressenbergs in Bezug auf ihre Darstellung in der Lethaea geognostica von Südbayern (pp. 129-170). Stuttgart: Neues Jahrbuch für Mineralogie, Geologie und Paläontologie.

Hagn, H., Darga, R. \& Schmid, R. (1992). Siegsdorf im Chiemgau. Erdgeschichte und Umwelt. $241 \mathrm{pp}$.

Hagn, H., \& Schmid, R. (1988). Fossilien von Neubeuern (p. 109). Neubeuern: Bilder aus der geologischen Vergangenheit.

Heim, Arnold. (1923a). Der Alpenrand zwischen Appenzell und Rheintal (Fähnern-Gruppe) und das Problem der Kreide-Nummuliten. Beiträge zur Geologischen Karte der Schweiz, [N. F.] $53,1-51$.

Heim, Arnold. (1923b). Neue Beobachtungen am Alpenrand zwischen Appenzell und Rheintal. Eclogae geologicae Helvetiae, 17, 347-349.

Heim, Albert (1905). Das Säntisgebirge. Textband. Beiträge zur Geologischen Karte der Schweiz, [N. F.] 16, 654.

Herb, R. (1962). Geologie von Amden mit besonderer Berücksichtigung der Flyschbildungen. Beiträge zur Geologischen Karte der Schweiz, [N. F.] 114, 130.

Herb, R. (1988). Eocaene Paläogeographie und Paläotektonik des Helvetikums. Eclogae geologicae Helvetiae, 81, 611-657.

Hertlein, L. G. \& Grant, U. S. (1944). The Cenozoic Brachiopoda of western North America. Los Angeles: Publications of the University of California in mathematical and physical sciences.Vol. 3, 236 pp.

Hiller, N., \& MacKinnon, D. I. (2000). A reappraisal of the systematics of the Stethothyris group of brachiopods from the Cenozoic of New Zealand and Australia. New Zealand Journal of Geology and Geophysics, 43, 59-81.

Kissling, E. (1896). Die Fauna des Mittel-Oligocäns im Berner Jura. Abhandlungen der Schweizerischen Paläontologischen Gesellschaft, 22(1895), 1-74.

Kürsteiner, P., \& Soom, M. (2007). Mineralien im Alpstein (p. 272). Herisau: Appenzeller Verlag.

Lee, D. E. \& Smirnova, T. N. (2006). Terebratuloidea. In: Treatise on Invertebrate Paleontology. Part H: Brachiopoda, revised, Vol. 5: Rhynchonelliformea (part). Geological Society of America, Inc. and The University of Kansas, pp. 2054-2081.

Leupold, W. (1966). Einsiedler Nummulitenkalke. In: Lexique stratigraphique internationale (Congrès géologique international, commission de stratigraphie), Vol. 1, Europe. Fascicule 7c: Schweizer Alpen und Südtessin, pp. 337-359.

Leymerie, M. A. (1846). Mémoire sur le terrain a Nummulites (Épicrétacé) des corbières et de la Montagne Noire. Mémoires de la Société Géologique de France [2] 1/2, 337-375.

MacKinnon, D. I., Beus, S. S., \& Lee, D. E. (1993). Brachiopod fauna of the Kokoamu Greensand (Oligocene), New Zealand. New Zealand Journal of Geology and Geophysics, 36, 327-347.

Makridin, V. P. (1964). Brachiopods from the Jurassic sediments of the Russian platform and some adjoining regions. GorkiiKharkov State University 394 pp. (in Russian).

Mayer, M. C. (1864). Description des coquilles fossiles des terrains tertiaires inférieurs (suite). Journal Conchyliologie, 12, 174.

Mayer, K. (1877). Systematisches Verzeichnis der Versteinerungen des Parisian der Umgegend von Einsiedeln. Beiträge zur Geologischen Karte der Schweiz, 14, 100.

Mayer, K. (1879). Das Londinian am Sentis. Vierteljahrsschrift der Naturforschenden Gesellschaft Zürich, 24, 77-86.

Mayer-Eymar, K. (1887). Systematisches Verzeichnis der Kreideund Tertiär-Versteinerungen der Umgegend von Thun. Beiträge zur Geologischen Karte der Schweiz, 24, 128. 
Mayer-Eymar, K. (1890). La faune miraculeuse du Londinien d'Appenzell. Vierteljahrsschrift der Naturforschenden Gesellschaft Zürich, 35, 167-181.

Megerle von Mühlfeldt, J. K. (1811). Entwurf eines neuen Systems der Schalthiergehäuse. Gesellschaft Naturforschender Freunde zu Berlin, Magazin, 5, 38-72.

Menkveld-Gfeller, U. (1997). Die Bürgen-Fm: und die KlimsenhornFm.: Formelle Definition zweier lithostratigraphischer Einheiten des Eozäns der helvetischen Decken. Eclogae geologicae Helvetiae, 90, 245-261.

Moesch, C. (1878). Zur Paläontologie des Sentisgebirges. In: A. Escher v. d. Linth (Ed.), Die Sentis-Gruppe (Vol. 13, pp. 18).

Motchurova-Dekova, N., Radulović, V., Graziano, R., \& TaddeiRuggiero, E. (2009). Orbirhynchia nadiae, a new rhynchonellide brachiopod species from the Lower Aptian of the Gargano Promontory (southern Italy): shell structure, stratigraphy palaeoecology and taphonomy. Neues Jahrbuch für Geologie und Paläontologie Abhandlungen, 252, 289-313.

Münster, G. (1828). Über die Versteinerungen aus dem feinkörnigen Thoneisenstein und dem grünen Sande am Kressenberge bei Braunstein in Baiern. Teutschland, geognostisch-geologisch dargestellt und mit Charten und Durchschnittszeichnungen erläutert, eine Zeitschrift, herausgegeben von Ch. Keferstein, Weimar, Vol. 6/1, 93-103.

Neall, V. E. (1970). Notes on the ecology and paleoecology of Neothyris, an endemic New Zealand brachiopod. New Zealand Journal of Marine and Freshwater Research, 4, 117-125.

Nilsson, S. (1827). Petrificata Suecana formationis cretaceae/descripta et iconibus illustra. Londini Gothorum: Ex Officina Belingsiana.

Nyst, M. P.-H. (1843). Description des coquilles et des polypiers fossils des terrains tertiaires de la Belgique. Mémoires couronnés et mémoires des savants étrangers, 17, 697.

Ooster, W.-A. (1863). Pétrifications remarquables des Alpes suisses. Synopsis des brachiopodes fossiles des Alpes suisses (p. 71). Genève: H. Georg.

Oppenheim, P. (1894). Die Eocaenfauna des Mt. Pulli bei Valdagno im Vicentino. Zeitschrift der deutschen geologischen Gesellschaft, 46, 309-445.

Oppenheim, P. (1896). Die Eocaenfauna des Monte Postale bei Bolca im Veronesischen. Palaeontographica, 43, 125-222.

Owen, E. F. (1980). Tertiary and Cretaceous brachiopods from Seymour, Cockburn and James Ross Islands, Antarctica. Bulletin of the British Museum (Natural History), 33, 123-145.

Pfiffner, O. A. (2000). Tektonik, pp. 39-48. In: H. Funk, J. K.Habicht, R. Hantke, \& O. A. Pfiffner(Eds.), Geologischer Atlas der Schweiz 1:25000. Erläuterungen zum Blatt 1115 Säntis, 1-17. Bundesamt für Wasser und Geologie.

Phillips, J. (1829). Illustrations of the Geology of Yorkshire; or, a description of the strata and organic remains of the Yorkshire Coast. York: Thomas Wilson and sons.

Quenstedt, F. A. (1868-1871). Petrefactenkunde Deutschlands. 1. Abt., 2. Band: Die Brachiopoden. Tübingen \& Leipzig. 1-160 (1868); 161-464 (1869); 465-748 (1870); 25 pl. (1871).

Radulović, V. (1991). Middle Jurassic brachiopods of Laz (Yugoslav Part of the Carpatho-Balkan Arch). Palaeontologia Jugoslavica, $40,1-36$.

Rasser, M. W., \& Piller, W. E. (1999a). Lithostratigraphische Neugliederung im Paläogen des österreichischen-bayerischen Südhelvetikums. Abhandlungen der geologischen Bundesanstalt Wien, 56, 699-712.
Rasser, M. W., \& Piller, W. E. (1999b). Kroisbachgraben und Frauengrube: Lithostratigraphische Typuslokalitäten für das paläogene Helvetikum in Salzburg. Abhandlungen der geologischen Bundesanstalt Wien, 56, 713-722.

Richardson, J. R. (1981). Distribution and orientation of six articulate brachiopod species from New Zealand. New Zealand Journal of Zoology, 8, 189-196.

Richardson, J. R., Aldridge, A. E., \& Endersby, I. D. (2007). Post settlement behaviour of brachiopods on hard and soft substrates. New Zealand Journal of Zoology, 34, 43-49.

Richter, M. (1925). Die Fähnernmulde am Nordrand des Säntis und das Problem der Kreide-Nummuliten. Geologische Rundschau, $16,81-99$.

Rollier, L. (1923). Supracrétacique et Nummulitique dans les Alpes suisses orientales. Matériaux pour la Carte géologique de la Suisse, [Nouvelle série], 53, 53-85.

Rutsch, R. (1928). Geologie des Belpbergs. Beiträge zur Kenntnis der Stratigraphie, Paläontologie und Tektonik der Molasse südlich von Bern. Mitteilungen der naturforschenden Gesellschaft Bern, 1927, 1-194.

Sahni, M. R. (1925). Morphology and zonal distribution of some chalk terebratulids. Annals and Magazine of Natural History (series 9), 15, 353-385.

Schafhäutl, K. E. (1863). Der Kressenberg und die südlich von ihm gelegenen Hochalpen, geognostisch betrachtet in ihren Petrefacten. Leipzig: Süd-Bayerns Lethaea Geognostica. L. Voss.

Schlosser, M. (1925). Die Eocaenfaunen der bayerischen Alpen. I. Teil: Die Faunen des Unter- und Mitteleocaen. Abhandlungen der bayerischen Akademie der Wissenschaften (München), 30/7, 206 pp.

Schultz, O. (1998). Tertiärfossilien Österreichs. Wirbellose, niedere Wirbeltiere und marine Säugetiere (p. 159). Korb: GoldschneckVerlag.

Steinich, G. (1965). Die artikulaten Brachiopoden der Rügener Schreibkreide (Unter-Maastricht): Geologische und Paläontologische Abhandlungen, Abt. A, 2/1, 220 pp.

Surlyk, F. (1972). Morphological adaptations and population structures of the Danish chalk brachiopods (Maastrichtian, Upper Cretaceous). Kongelige Danske Videnskabernes Selskabs, Biologiske Skrifter, 19, 2-57.

Tchorszhevskiy, E. S. (1993). New data about structural elements of cardinalium and brachidium of Jurassic Terebratulida. Mesozoic Brachiopods of Alpine Europe. In: Palfy, Vörös (Eds.), Budapest: Hungarian Geological Society pp. 151-159.

Thomson, J. A. (1927). Brachiopod morphology and genera (recent and Tertiary). New Zealand Board of Science and Art, Manual, 7, 1-338.

Vincent, E. G. (1893). Contribution à la paléontologie des terrains tertiaires de la Belgique: Brachiopodes. Société Royale Malacologique de Belgique, Annales, 28, 38-64.

Vincent, E. G. (1923). Quelques remarques sur des brachiopodes tertiaires de Belgique et description d'une espèce nouvelle d'Argyrotheca. Société Royale Malacologique de Belgique, Annales, 53, 49-53.

Vogl, V. (1912). Die Fauna der Eozän-Mergel im Vinodol in Kroatien. Jahrbuch der Ungarischen Geologischen Reichsanstalt, Budapest, 20, 81-114.

Zelinskaya, V. A. (1975). Brakhiopody Paleogena Ukrainy (Brachiopods of the Palaeogene of the Ukraine, in russian) (p. 147). Kiew: Naukova Dumka. 